\title{
HTGR Cost Model Users' Manual
}

\author{
Anastasia M. Gandrik
}

The INL is a

U.S. Department of Energy National Laboratory

operated by

Battelle Energy Alliance

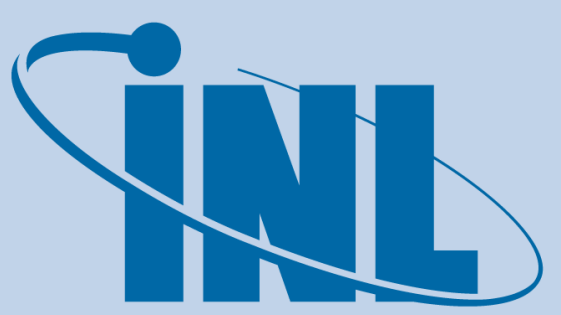

Idaho National Laboratory
January 2012

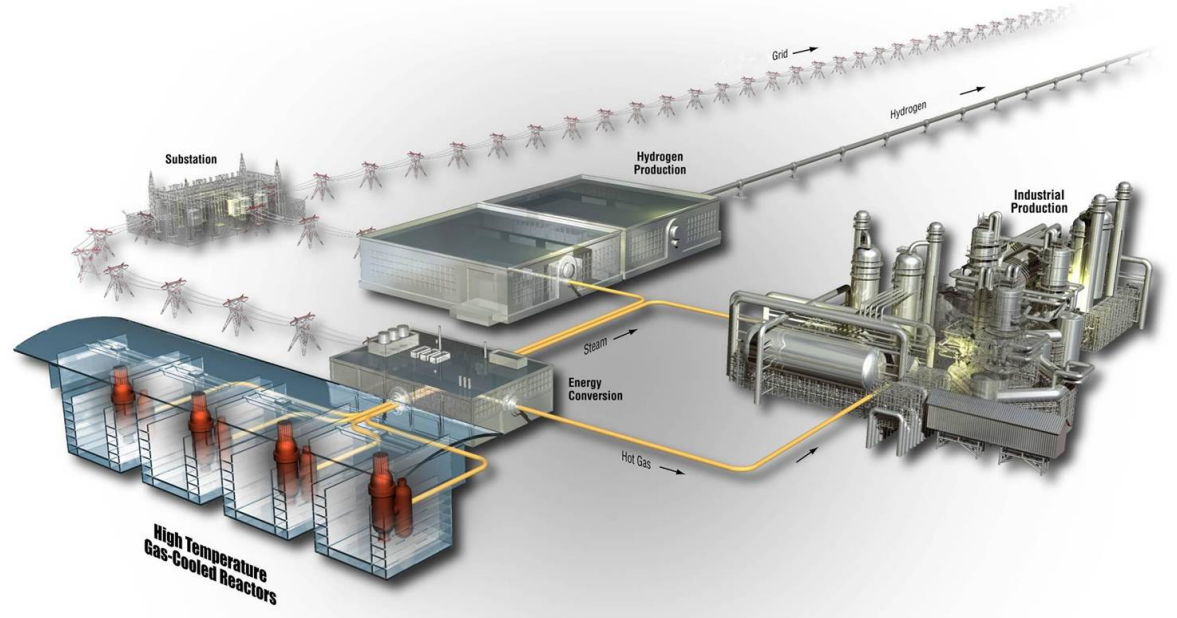




\section{DISCLAIMER}

This information was prepared as an account of work sponsored by an agency of the U.S. Government. Neither the U.S. Government nor any agency thereof, nor any of their employees, makes any warranty, expressed or implied, or assumes any legal liability or responsibility for the accuracy, completeness, or usefulness, of any information, apparatus, product, or process disclosed, or represents that its use would not infringe privately owned rights. References herein to any specific commercial product, process, or service by trade name, trade mark, manufacturer, or otherwise, does not necessarily constitute or imply its endorsement, recommendation, or favoring by the U.S. Government or any agency thereof. The views and opinions of authors expressed herein do not necessarily state or reflect those of the U.S. Government or any agency thereof. 
INL/EXT-11-23833

Revision 1

\section{HTGR Cost Model Users' Manual}

Anastasia M. Gandrik

January 2012

\section{Idaho National Laboratory \\ Next Generation Nuclear Plant Project \\ Idaho Falls, Idaho 83415}

http://www.inl.gov

Prepared for the

U.S. Department of Energy

Office of Nuclear Energy

Under DOE Idaho Operations Office

Contract DE-AC07-05ID14517 



\title{
Next Generation Nuclear Plant Project
}

\section{HTGR Cost Model Users' Manual}

\author{
INL/EXT-11-23833
}

Revision 1

January 2012

Approved by:
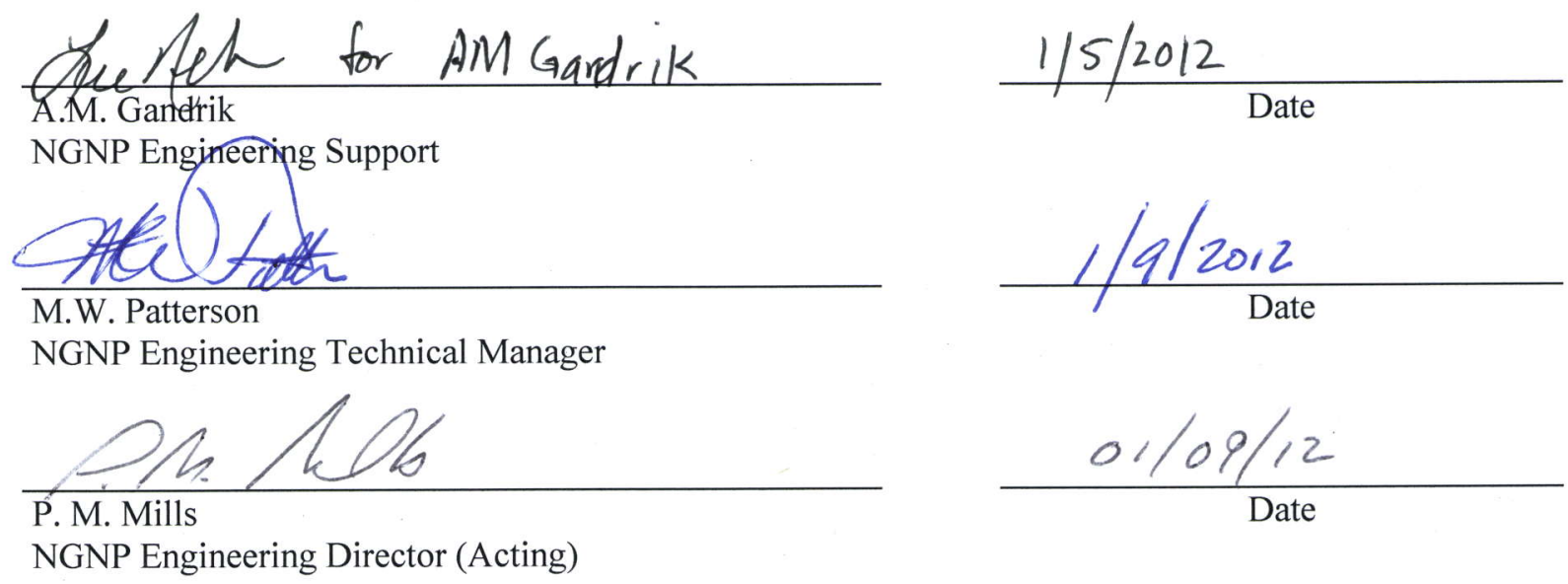

NGNP Engineering Director (Acting) 



\begin{abstract}
The High Temperature Gas-Cooled Reactor (HTGR) Cost Model was developed at the Idaho National Laboratory for the Next Generation Nuclear Plant Project. The HTGR Cost Model calculates an estimate of the capital costs, annual operating and maintenance costs, and decommissioning costs for an HTGR. The user can generate these costs for multiple reactor outlet temperatures; with and without power cycles, including either a Brayton or Rankine cycle; for the demonstration plant, first of a kind, or $n^{\text {th }}$ of a kind project phases; for a single or four-pack configuration; and for a reactor size of 350 or $600 \mathrm{MWt}$.

This users' manual contains the mathematical models and operating instructions for the HTGR Cost Model. Instructions, screenshots, and examples are provided to guide the user through the HTGR Cost Model. This model was designed for users who are familiar with the HTGR design and Excel.

Modification of the HTGR Cost Model should only be performed by users familiar with Excel and Visual Basic.
\end{abstract}




\section{CONTENTS}

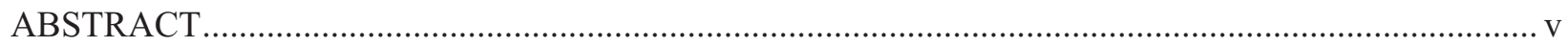

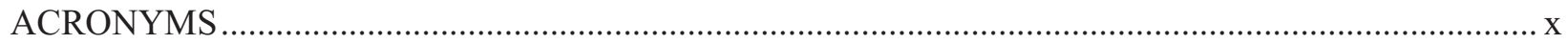

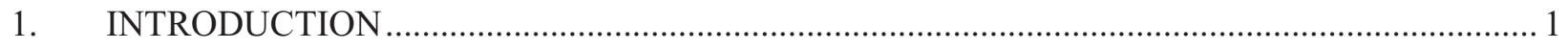

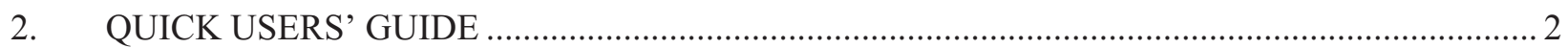

3. DETAILED WORKSHEET DESCRIPTIONS ...................................................................... 4

3.1 HTGR Cost Summary Worksheet.............................................................................. 4

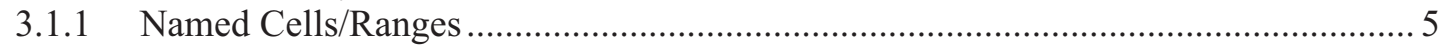

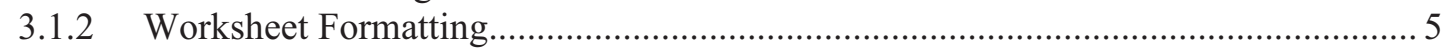

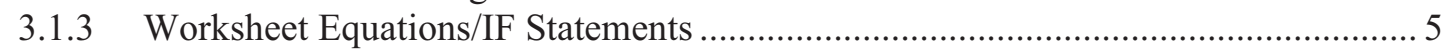

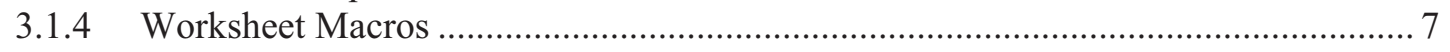

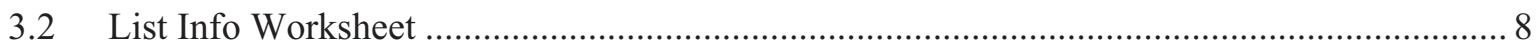

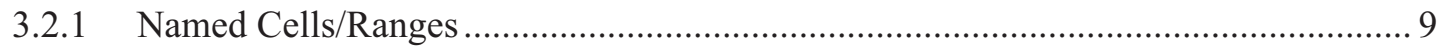

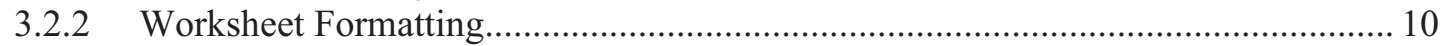

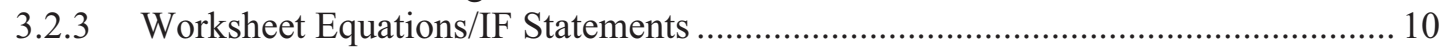

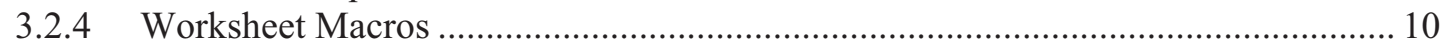

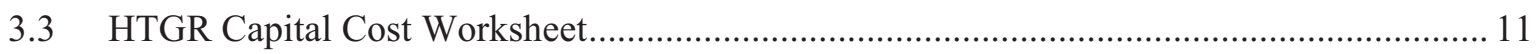

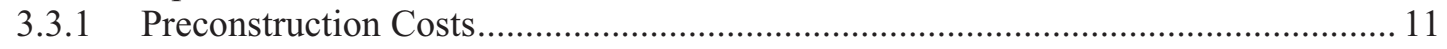

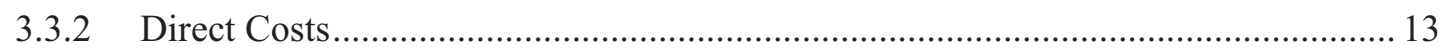

3.3.3 Indirect Costs and Total Overnight Capital Costs................................................ 14

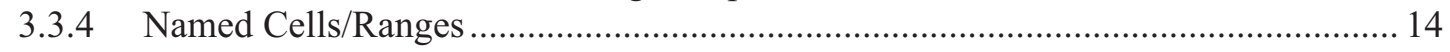

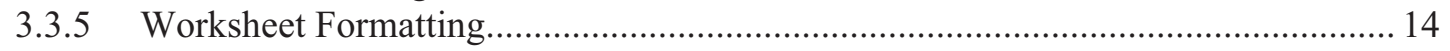

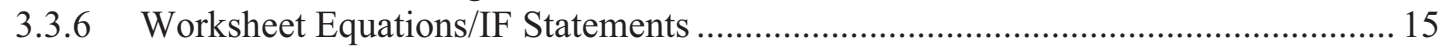

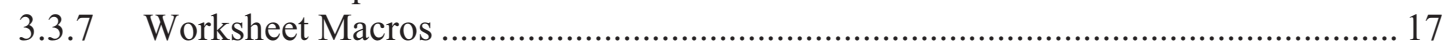

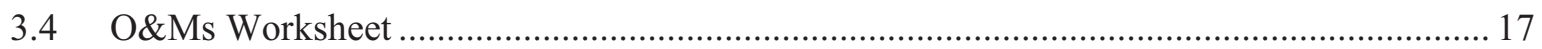

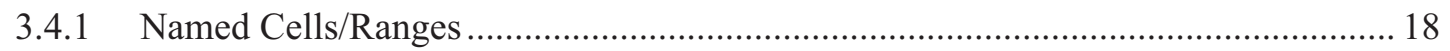

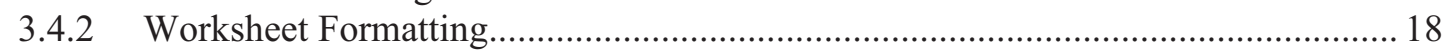

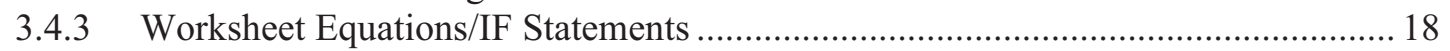

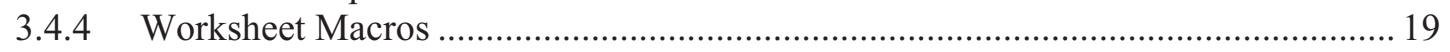

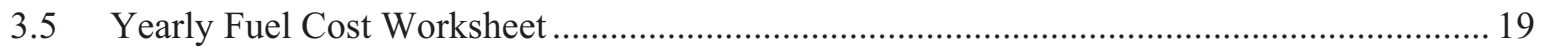

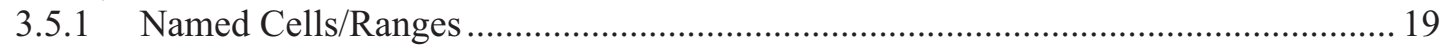

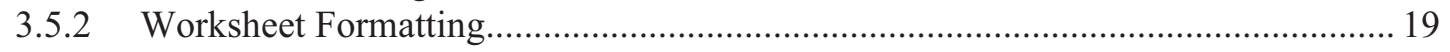

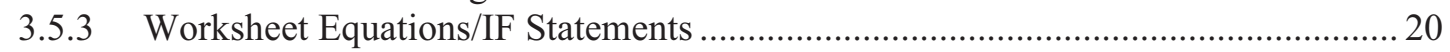

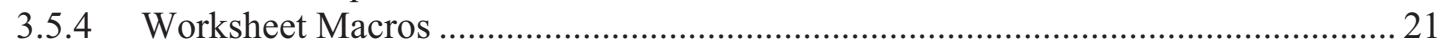

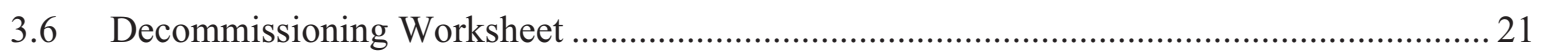

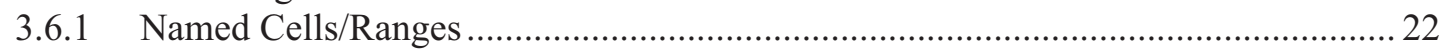

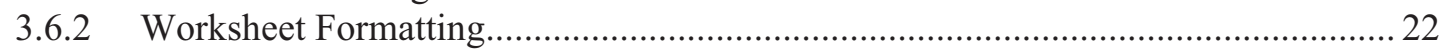

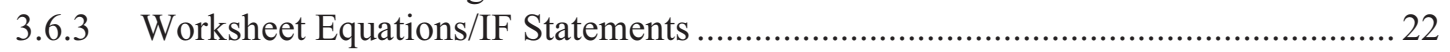

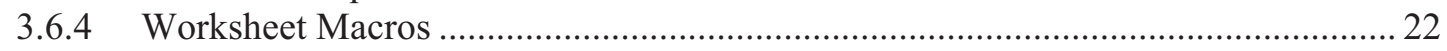

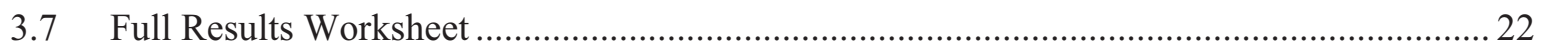

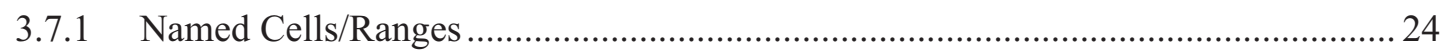

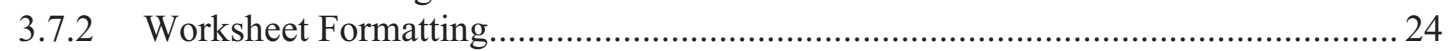

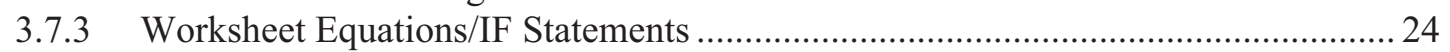

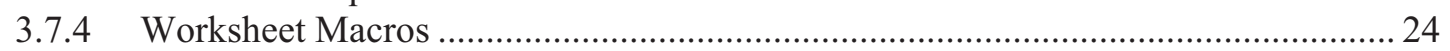




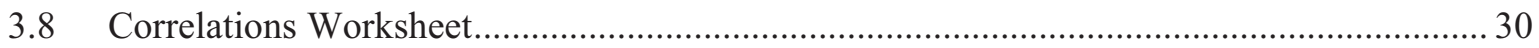

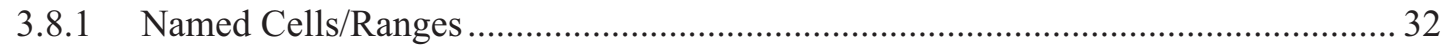

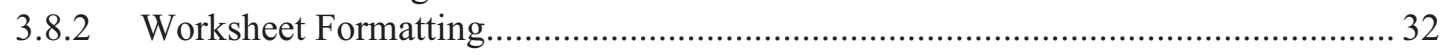

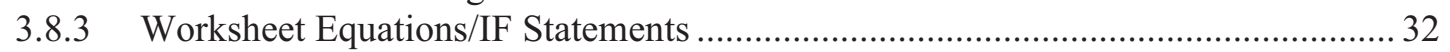

3.8.4 Worksheet Macros .............................................................................................. 33

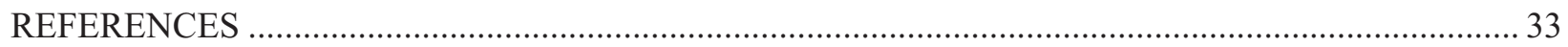

\section{FIGURES}

Figure 1. HTGR Cost Model, quick users' guide screenshot. ............................................................ 3

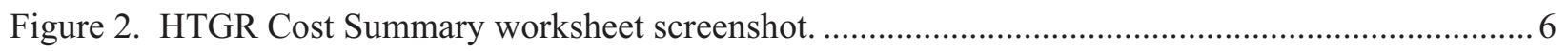

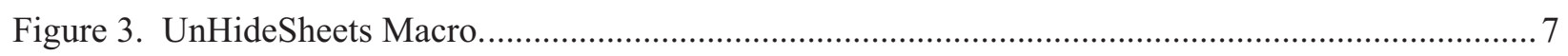

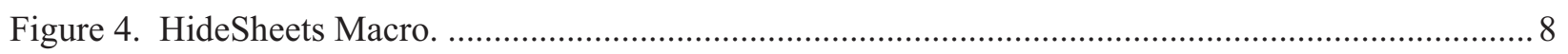

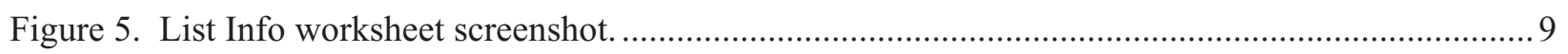

Figure 6. Reactor input summary on the HTGR Capital Cost worksheet, screenshot............................. 11

Figure 7. Preconstruction costs on the HTGR Capital Cost worksheet, screenshot. ............................... 12

Figure 8. Direct costs on the HTGR Capital Cost worksheet, screenshot. ............................................. 13

Figure 9. Indirect and total overnight costs on the HTGR Capital Cost worksheet, screenshot............... 15

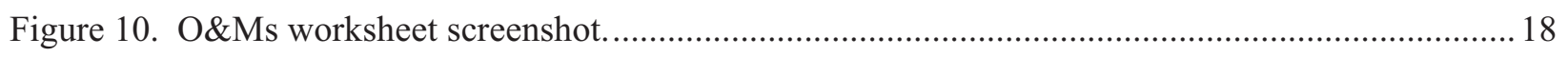

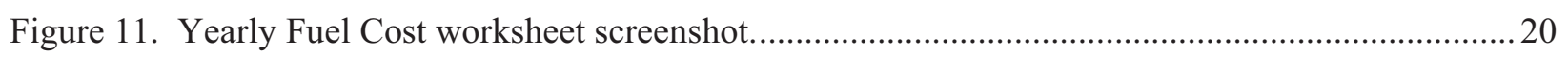

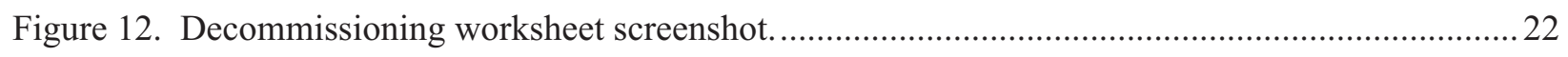

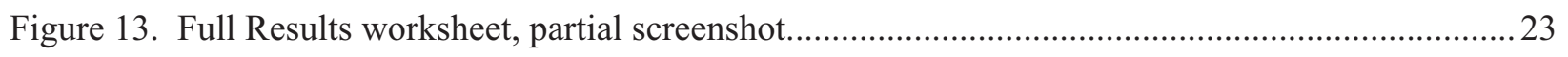

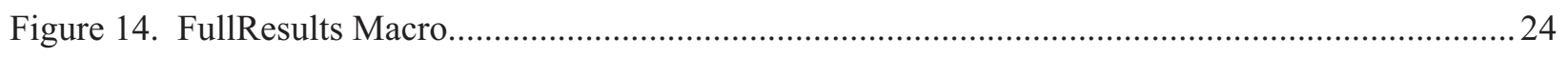

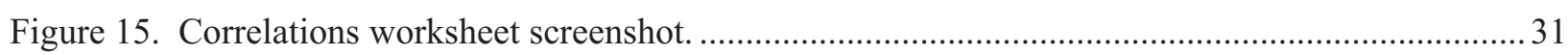

\section{TABLES}

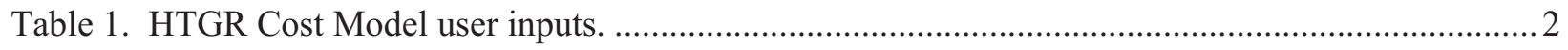

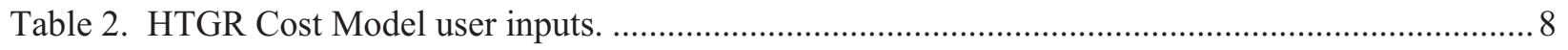




\section{ACRONYMS}

AACE Association for the Advancement of Cost Engineering

CEPCI chemical engineering plant cost index

DOE Department of Energy

FOAK first of a kind

HTGR high temperature gas-cooled reactor

INL Idaho National Laboratory

LWR light water reactor

NGNP Next Generation Nuclear Plant

NOAK nth of a kind

O\&M operations and maintenance

ROT reactor outlet temperature

SWU separative work unit 


\section{HTGR Cost Model \\ Users' Manual}

\section{INTRODUCTION}

The Next Generation Nuclear Plant (NGNP) Project is being conducted under U.S. Department of Energy (DOE) direction to meet a national strategic need identified in the 2005 Energy Policy Act to promote reliance on safe, clean, economic nuclear energy and to establish a greenhouse-gas-free technology for the production of hydrogen. The NGNP represents an integration of high-temperature reactor technology with advanced hydrogen, electricity, and process heat production capabilities, thereby meeting the mission need identified by DOE. The strategic goal of the NGNP Project is to broaden the environmental and economic benefits of nuclear energy in the U.S. economy by demonstrating its applicability to market sectors not being served by light water reactors. A high temperature gas-cooled reactor (HTGR) differs from a third generation light water reactor by using helium instead of water as the coolant, graphite instead of water as the moderator, and tristructural isotropic fuel instead of metal-clad fuel. With these features, an HTGR is capable of operating at higher temperatures, which offers a broader application to industrial processes and higher thermal efficiencies than are achievable with the lower operating temperatures of light water reactors.

The HTGR can be applied in many industrial applications as a substitute for burning of fossil fuels, including natural gas and coal, in addition to producing electricity. An objective of the NGNP Project is to evaluate the economics of heat and power production from an HTGR for incorporation into a variety of chemical processes, as well as for more traditional electricity production. However, in order to properly assess the economics of HTGR integration, it was first necessary to determine the capital costs, operating and maintenance (O\&M) costs, and decommissioning costs of the HTGR. This was accomplished through the creation of the HTGR Cost Model which was used to generate the costs documented in TEV-1196, Assessment of High Temperature Gas-Cooled Reactor (HTGR) Capital and Operating Costs (Idaho National Laboratory [INL] 2011).

This users' manual contains the mathematical models and operating instructions for the HTGR Cost Model. Instructions, screenshots, and examples are provided to guide the user through the HTGR Cost Model. This model was designed for users who are familiar with the HTGR design and Excel.

Modification of the HTGR Cost Model should only be performed by users familiar with Excel and Visual Basic. The bases and assumptions for the cost model are covered in TEV-1196 and will not be discussed in the associated users' manual; rather the users' manual will only discuss the model methodology.

The cost model was developed to estimate HTGR costs for a range of reactor outlet temperatures (ROT), $750^{\circ} \mathrm{C}$ to $950^{\circ} \mathrm{C}$, in $50^{\circ} \mathrm{C}$ increments; with and without power cycles, including both Rankine and Brayton cycles; for single and four-pack reactor configurations; for both $350 \mathrm{MWt}$ and $600 \mathrm{MWt}$ power levels; for the NGNP, first of a kind (FOAK), and nth of a kind (NOAK) project phases. A four-pack reactor plant includes four reactor vessels with shared control facilities. The NGNP plant is the initial demonstration of the current HTGR design, a FOAK plant is the first commercial installation of the HTGR technology, while the NOAK plant is a mature commercial installation of the HTGR technology. O\&M costs were developed from reactor vendor labor estimates and INL labor estimates, as described in TEV-1196 (INL 2011).

Capital cost estimates are based on estimates provided by Dominion Engineering, Inc. for the INL through a separate subcontract. This users' manual does not address Dominion's estimate, which is presented and discussed in TEV-1196 (INL 2011). The Association for the Advancement of Cost Engineering (AACE) International recognizes five classes of estimates. The level of project definition for 
this study was determined to be an AACE International Class 4 estimate, which has a probable error of $-30 \%$ and $+50 \%$, as described in TEV-1196 (INL 2011). A Class 4 estimate is associated with a feasibility study or top-down cost estimate and has one to fifteen percent of full project definition (AACE 2005).

\section{QUICK USERS' GUIDE}

The HTGR Cost Model (HTGR Cost Model.xlsm) can be used to quickly generate the capital, O\&M, fuel, and decommissioning costs for a variety of HTGR configurations in 2009 dollars. After the Excel file is opened, the user is presented with the HTGR Cost Summary worksheet; next the user selects the desired configuration from the combo boxes labeled Reactor Inputs (cells D2 to D8); and the corresponding capital, O\&M, fuel, and decommissioning costs are presented for the selected HTGR configuration (cells F12 to F41). All costs are calculated as described in TEV-1196 (INL 2011).

Table 1 outlines the reactor inputs available in the combo boxes and Figure 1 presents a screenshot of the HTGR Cost Summary worksheet for four- $600 \mathrm{MWt} 850^{\circ} \mathrm{C}$ ROT HTGRs with Rankine Power Cycles, for the NOAK project phase, and the vendor staffing plan. Advanced users can unhide the other worksheets used in the model, by clicking the Unhide Sheets button, if they wish to update, review, or change the underlying data. The Hide Sheet button hides the detailed worksheets. The detailed worksheet descriptions are presented in Section 3.

Table 1. HTGR Cost Model user inputs.

\begin{tabular}{c|c|c|c|c|c|c}
\hline $\begin{array}{c}\text { Reactor } \\
\text { Size (MWt) }\end{array}$ & ROT $\left({ }^{\circ} \mathbf{C}\right)$ & $\begin{array}{c}\text { Project } \\
\text { Phase }\end{array}$ & $\begin{array}{c}\text { Number of } \\
\text { Reactors }\end{array}$ & $\begin{array}{c}\text { Power Cycle } \\
\text { Present }\end{array}$ & $\begin{array}{c}\text { Power } \\
\text { Cycle Type }\end{array}$ & $\begin{array}{c}\text { Staffing } \\
\text { Plan }\end{array}$ \\
\hline 350 & 750 & NGNP & 1 & Yes & Rankine & Vendor \\
600 & 800 & FOAK & 4 & No & Brayton & INL Model \\
& 850 & NOAK & & & & \\
& 900 & & & & & \\
\hline
\end{tabular}




\begin{tabular}{|c|c|c|c|c|c|c|}
\hline 4 & A & B & $\mathrm{C}$ & D & $E$ & $\mathrm{~F}$ \\
\hline 1 & \multicolumn{3}{|c|}{ Reactor Inputs: } & & & \\
\hline 2 & & \multicolumn{2}{|c|}{ Reactor Size (MWt): } & 600 & \multicolumn{2}{|c|}{ Hide Sheets } \\
\hline 3 & & \multicolumn{2}{|c|}{ ROT $\left({ }^{\circ} \mathrm{C}\right)$ : } & 850 & & \\
\hline 4 & & \multicolumn{2}{|c|}{ Project Phase: } & NOAK & \multicolumn{2}{|c|}{ Unhide Sheets } \\
\hline 5 & & \multicolumn{2}{|c|}{ Number of Reactors: } & $\nabla$ & & \\
\hline 6 & & \multicolumn{2}{|c|}{ Power Cycle Present: } & Yes & & \\
\hline 7 & & \multicolumn{2}{|c|}{ Power Cycle Type: } & Rankine & & \\
\hline 8 & & \multicolumn{2}{|c|}{ Staffing Plan: } & Vendor & & \\
\hline \multicolumn{7}{|l|}{9} \\
\hline 10 & \multicolumn{4}{|c|}{ Capital Cost Summary (Million 2009 \$): } & & \\
\hline 11 & & \multicolumn{3}{|c|}{ PRECONSTRUCTION COSTS: } & & \\
\hline 12 & & \multicolumn{3}{|c|}{ Land and Land Rights } & & 10.00 \\
\hline 13 & & \multicolumn{3}{|c|}{ Licensing and Application Costs } & & 81.00 \\
\hline 14 & & \multicolumn{3}{|c|}{ TOTAL PRECONSTRUCTION COSTS } & & 91.00 \\
\hline 15 & & \multicolumn{2}{|c|}{ DIRECT COSTS } & & & \\
\hline 16 & & \multicolumn{4}{|c|}{ Selected Configuration Direct Cost Total } & 2052.42 \\
\hline 17 & & \multicolumn{3}{|c|}{ Balance of Equipment Adder: } & & 513.11 \\
\hline 18 & & \multicolumn{2}{|c|}{ TOTAL DIRECT COSTS: } & & & 2565.53 \\
\hline 19 & & \multicolumn{2}{|c|}{ INDIRECT COSTS: } & & & \\
\hline 20 & & & \multicolumn{2}{|l|}{ Total Design Costs: } & & 20.00 \\
\hline 21 & & & \multicolumn{2}{|c|}{ Construction Services: } & & 514.11 \\
\hline 22 & & & \multicolumn{3}{|c|}{ Home Office and Engineering Services: } & 413.66 \\
\hline 23 & & & Field Office and En & gineering Serv & & 250.69 \\
\hline 24 & & & Owner's Costs: & & & 295.75 \\
\hline 25 & & TOT, & AL INDIRECT COSTS: & & & 1494.20 \\
\hline 26 & & BAS & E CONSTRUCTION CO & OST: & & 4150.73 \\
\hline 27 & & PRO & DJECT CONTINGENCY: & & & 830.15 \\
\hline 28 & & TOT, & AL OVERNIGHT COST & & & 4980.88 \\
\hline 29 & & OVE & RNIGHT COST PER $\mathrm{kV}$ & $W t(\$ / k W t):$ & & 2075.37 \\
\hline 30 & & & & & & \\
\hline 31 & Yea & rly Or & \&M Summary (Millio & on 2009 \$): & & \\
\hline 32 & & Toto & al Yearly O\&M Cost: & & & 99.60 \\
\hline 33 & & O\&N & $M$ Cost Per MWt-hr $(\$$ & $(\$ / M W t-h r)$ & & 4.74 \\
\hline 34 & & & & & & \\
\hline 35 & Fue & Cost & t Summary (Million 2 & 2009 \$): & & \\
\hline 36 & & Refu & Jeling Cost Per Core: & & & 50.21 \\
\hline 37 & & Toto & al Average Yearly Fue & el Cost: & & 133.88 \\
\hline 38 & & Fuel & I Cost Per MWt-hr (\$) & $(M W t-h r)$ & & 6.37 \\
\hline 39 & & & & & & \\
\hline 40 & Dec & omm & hissioning Cost Summ & nary (Million 2 & 9 \$): & \\
\hline 41 & & Tota & al Decommissioning & Costs: & & 491.47 \\
\hline 14 & 11 & & IGR Cost Sumn & है & & \\
\hline
\end{tabular}

Figure 1. HTGR Cost Model, quick users' guide screenshot. 


\section{DETAILED WORKSHEET DESCRIPTIONS}

The HTGR Cost Model (HTGR Cost Model.xlsm) is implemented in an Excel spreadsheet with Visual Basic Macros enabled; the model was developed in Excel 2007 for Windows operating systems (Excel 2007). However, the model has been successfully operated in other versions of Excel on various operating systems. Still, this users' manual assumes the user is running Excel 2007 for Windows and all screenshots are from this version. The following worksheets are included in the model:

- $\quad$ HTGR Cost Summary

- List Info

- HTGR Capital Cost

- O\&Ms

- Yearly Fuel Cost

- Decommissioning

- Full Results

- Correlations

To ensure Macros are enabled click the 'Office Button' and select 'Excel Options'. Click the 'Trust Center' tab on the far left of the 'Excel Options' window, and click the 'Trust Center Settings' button. On the far left of the 'Trust Center Settings' window click 'Macro Settings' and ensure 'Enable all macros (not recommended; potentially dangerous code can run)' is selected. To edit Macros ensure that the 'Show Developer' tab in the 'Ribbon' is checked in the 'Popular' tab of the 'Excel Options' window, next click the 'Developer' tab in the 'Ribbon' and click the 'Macros' button. Select the Macro you wish to edit and click 'Edit'.

The following sections are arranged such that the approach for each worksheet is summarized, followed by a section which defines any named cells or ranges, a section explaining any special formatting, a section defining equations and IF statements contained in the worksheet, and finally a section listing Macros used in the worksheet. Special formatting may include cells highlighted a certain color identifying user inputs, etc. Equations and IF statements defined do not include every equation or function used in the workbook, rather complex equations are only specified, i.e. functions which use simple sums and averages are not necessarily defined, unless they include an IF statement or lookup function.

All screenshots are presented for an NOAK, four-pack of 600 MWt HTGRs with Rankine power cycles, for an ROT of $850^{\circ} \mathrm{C}$, and the vendor staffing plan.

\subsection{HTGR Cost Summary Worksheet}

The HTGR Cost Summary worksheet is arranged such that the user selects the reactor inputs from several combo boxes. Based on these selections, the capital costs, yearly O\&M costs, fuel costs, and decommissioning costs calculated in the workbook are summarized in the HTGR Cost Summary worksheet. Costs are reported in millions of U.S. dollars per the year specified by the user on the List Info worksheet, the default year is 2009 . From the combo boxes the user specifies the following inputs: 
- Reactor size

- ROT

- Project phase

- Number of reactors

- Power cycle present

- Power cycle type

- Staffing plan

After the selections are made, the capital cost summary is populated based on outputs from the HTGR Capital Cost worksheet, the yearly O\&M cost summary is populated based on outputs from the O\&Ms worksheet, the fuel cost summary is populated based on outputs from the Yearly Fuel Costs worksheet, and the decommissioning cost summary is populated based on outputs from the Decommissioning worksheet. A screenshot of the HTGR Cost Summary sheet is presented in Figure 2.

Advanced users can unhide the worksheets used in the model, by clicking the Unhide Sheets button, if they wish to update, review, or change the underlying data. The Hide Sheets button hides the detailed worksheets. The Unhide Sheets button is linked to the UnHideSheets Macro and the Hide Sheets button is linked to the HideSheets Macro.

\subsubsection{Named Cells/Ranges}

ResultsSummary refers to the cell range F12:F41.

\subsubsection{Worksheet Formatting}

No special formatting is used on the HTGR Cost Summary worksheet.

\subsubsection{Worksheet Equations/IF Statements}

The values in the combo boxes are populated based on the data contained in the List Info worksheet. To edit or add to the data in the combo boxes the user must right-click the combo box to be edited and select 'Format Control'. Next, select the 'Control' tab, where the 'Input range' and 'Cell link' cell references are shown. Select the corresponding named cell range to be included from the List Info worksheet for the input range and the appropriate cell link on the List Info worksheet. 


\begin{tabular}{|c|c|c|c|c|c|c|}
\hline 4 & A & B & $\mathrm{C}$ & D & E & $\mathrm{F}$ \\
\hline 1 & \multicolumn{3}{|c|}{ Reactor Inputs: } & & & \\
\hline 2 & & \multicolumn{2}{|c|}{ Reactor Size (MWt): } & 600 & \multicolumn{2}{|c|}{ Hide Sheets } \\
\hline 3 & & \multicolumn{2}{|c|}{ ROT $\left({ }^{\circ} \mathrm{C}\right):$} & 850 & & \\
\hline 4 & & \multicolumn{2}{|c|}{ Project Phase: } & NOAK & \multicolumn{2}{|c|}{ Unhide Sheets } \\
\hline 5 & & \multicolumn{2}{|c|}{ Number of Reactors: } & $\nabla$ & & \\
\hline 6 & & \multicolumn{2}{|c|}{ Power Cycle Present: } & Yes & & \\
\hline 7 & & \multicolumn{2}{|c|}{ Power Cycle Type: } & Rankine & & \\
\hline 8 & & \multicolumn{2}{|c|}{ Staffing Plan: } & Vendor & & \\
\hline \multicolumn{7}{|l|}{9} \\
\hline 10 & \multicolumn{4}{|c|}{ Capital Cost Summary (Million 2009 \$): } & & \\
\hline 11 & & \multicolumn{3}{|c|}{ PRECONSTRUCTION COSTS: } & & \\
\hline 12 & & \multicolumn{3}{|c|}{ Land and Land Rights } & & 10.00 \\
\hline 13 & & \multicolumn{3}{|c|}{ Licensing and Application Costs } & & 81.00 \\
\hline 14 & & \multicolumn{3}{|c|}{ TOTAL PRECONSTRUCTION COSTS } & & 91.00 \\
\hline 15 & & \multicolumn{2}{|c|}{ DIRECT COSTS } & & & \\
\hline 16 & & \multicolumn{4}{|c|}{ Selected Configuration Direct Cost Total } & 2052.42 \\
\hline 17 & & \multicolumn{3}{|c|}{ Balance of Equipment Adder: } & & 513.11 \\
\hline 18 & & \multicolumn{2}{|c|}{ TOTAL DIRECT COSTS: } & & & 2565.53 \\
\hline 19 & & \multicolumn{2}{|c|}{ INDIRECT COSTS: } & & & \\
\hline 20 & & \multicolumn{3}{|c|}{ Total Design Costs: } & & 20.00 \\
\hline 21 & & \multicolumn{3}{|c|}{ Construction Services: } & & 514.11 \\
\hline 22 & & \multicolumn{4}{|c|}{ Home Office and Engineering Services: } & 413.66 \\
\hline 23 & & \multicolumn{4}{|c|}{ Field Office and Engineering Services: } & 250.69 \\
\hline 24 & & & Owner's Costs: & & & 295.75 \\
\hline 25 & & TOTA & ALINDIRECT COSTS: & & & 1494.20 \\
\hline 26 & & $B A S E$ & E CONSTRUCTION CC & DST: & & 4150.73 \\
\hline 27 & & PRO. & JECT CONTINGENCY: & & & 830.15 \\
\hline 28 & & TOTA & AL OVERNIGHT COST & & & 4980.88 \\
\hline 29 & & OVEF & RNIGHT COST PER $k \mid$ & $W t(\$ / k W t):$ & & 2075.37 \\
\hline 30 & & & & & & \\
\hline 31 & Year & rly 08 & SM Summary (Millic & on 2009 \$): & & \\
\hline 32 & & Tota & 1 Yearly O\&M Cost: & & & 99.60 \\
\hline 33 & & $O \& N$ & A Cost Per MWt-hrl & $S / M W t-h r)$ & & 4.74 \\
\hline 34 & & & & & & \\
\hline 35 & Fuel & Cost & Summary (Million & 2009 \$): & & \\
\hline 36 & & Refu & eling Cost Per Core: & & & 50.21 \\
\hline 37 & & Tota & I Average Yearly Fue & Cost: & & 133.88 \\
\hline 38 & & Fuel & Cost Per MWt-hr (S, & (MWt-hr) & & 6.37 \\
\hline 39 & & & & & & \\
\hline 40 & Decc & ommi & issioning Cost Sumn & nary (Million 2 & 9 \$): & \\
\hline 41 & & Tota & I Decommissioning & Costs: & & 491.47 \\
\hline
\end{tabular}

Figure 2. HTGR Cost Summary worksheet screenshot. 


\subsubsection{Worksheet Macros}

The UnHideSheets Macro unhides the hidden sheets in the workbook when the user clicks the Unhide Sheets button, which by default includes the following worksheets:

- List Info

- HTGR Capital Cost

- O\&Ms

- Yearly Fuel Cost

- Decommissioning

- Full Results

- Correlations

The UnHideSheets Macro is presented in Figure 3. The HideSheets Macro hides all sheets in the workbook, except the HTGR Cost Summary sheet, when the user clicks the Hide Sheets button. The HideSheets Macro is show in Figure 4.

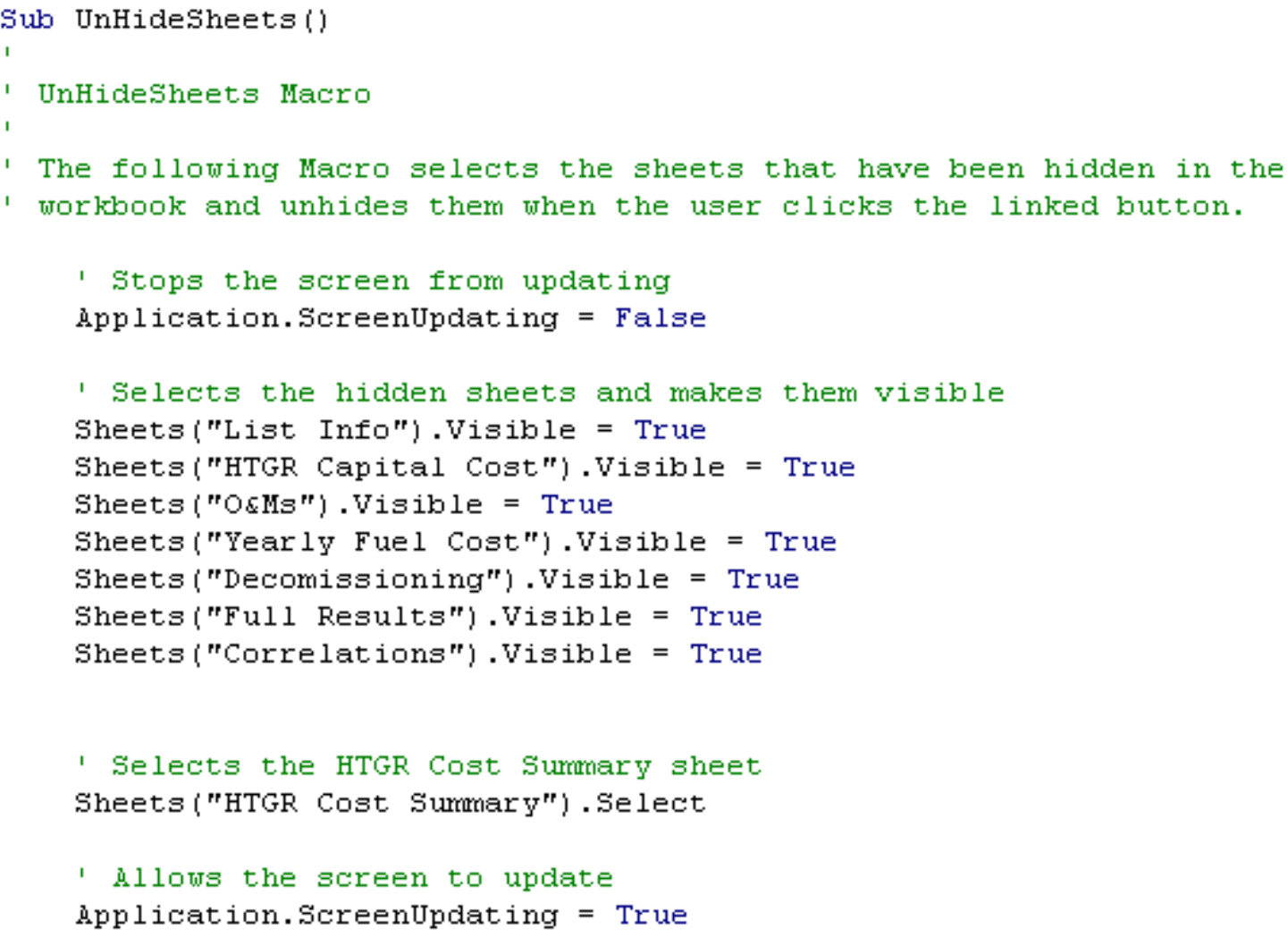

End Sub

Figure 3. UnHideSheets Macro. 


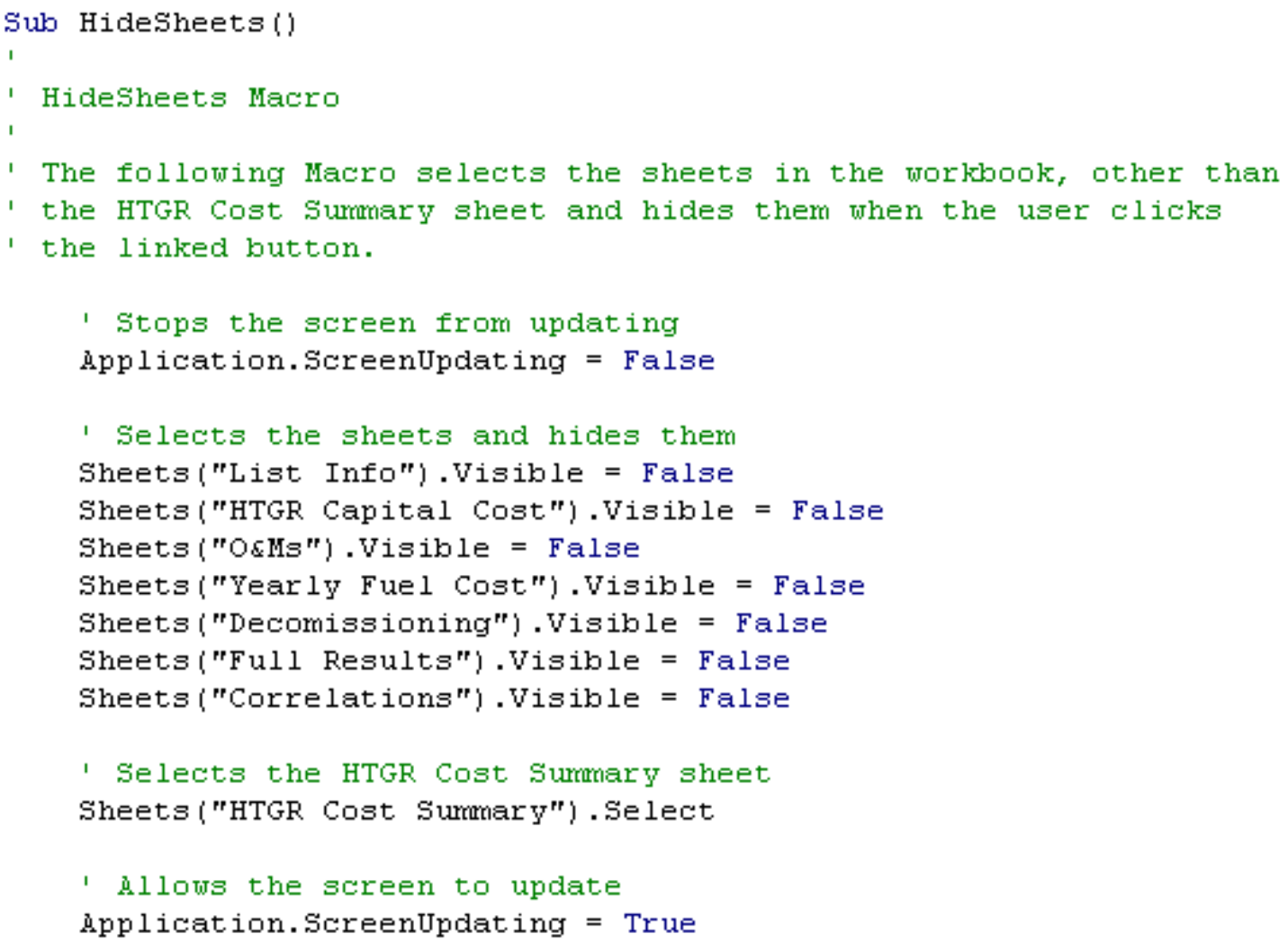

Figure 4. HideSheets Macro.

\subsection{List Info Worksheet}

The List Info worksheet provides the data which populates the combo boxes on the HTGR Cost Summary worksheet. Based on the value selected in the combo boxes on the HTGR Cost Summary worksheet, the appropriate cell link value is written to the cell for the corresponding reactor variable (row 8). Based on the cell link value, the value selected in the combo box is written to the cell for the corresponding reactor variable (row 10). The following table provides the user inputs and possible values used in the HTGR Cost Model:

Table 2. HTGR Cost Model user inputs.

\begin{tabular}{c|c|c|c|c|c|c}
\hline $\begin{array}{c}\text { Reactor } \\
\text { Size (MWt) }\end{array}$ & ROT $\left({ }^{\circ} \mathbf{C}\right)$ & $\begin{array}{c}\text { Project } \\
\text { Phase }\end{array}$ & $\begin{array}{c}\text { Number of } \\
\text { Reactors }\end{array}$ & $\begin{array}{c}\text { Power Cycle } \\
\text { Present }\end{array}$ & $\begin{array}{c}\text { Power } \\
\text { Cycle Type }\end{array}$ & $\begin{array}{c}\text { Staffing } \\
\text { Plan }\end{array}$ \\
\hline 350 & 750 & NGNP & 1 & Yes & Rankine & Vendor \\
600 & 800 & FOAK & 4 & No & Brayton & INL Model \\
& 850 & NOAK & & & & \\
& 900 & & & & & \\
\hline
\end{tabular}

The analysis year, inflation rate, and analysis year Chemical Engineering Plant Cost Index (CEPCI) are also included on the List Info worksheet. All costs are scaled based on 2009 dollars, which has a corresponding CEPCI of 521.9. To adjust capital costs from 2009 dollars to a later year, the capital costs 
are multiplied by the ratio of the CEPCIs. For instance, the CEPCI of 2010 is 550.8; therefore the 2009 base capital costs would be multiplied by 550.8/521.9 to adjust capital costs to 2010 dollars. An inflation rate of $3 \%$ is assumed to adjust O\&M, fuel, and decommissioning costs to years other than 2009 . To adjust costs from 2009 dollars the following equation is used:

$$
\text { Cost in } 2009 \text { dollars } \times(1+3 \%)^{(\text {Analysis Year-2009) }}
$$

Figure 5 presents a screenshot of the List Info worksheet.

\begin{tabular}{|c|c|c|c|c|c|c|c|}
\hline 4 & A & B & $\mathrm{C}$ & D & $\mathrm{E}$ & $\mathrm{F}$ & G \\
\hline 1 & Reactor Size & ROT & $\begin{array}{c}\text { Project } \\
\text { Phase }\end{array}$ & $\begin{array}{c}\text { Number of } \\
\text { Reactors }\end{array}$ & $\begin{array}{c}\text { Power Cycle } \\
\text { Present } \\
\end{array}$ & $\begin{array}{c}\text { Power Cycle } \\
\text { Type }\end{array}$ & Staffing Plan \\
\hline 2 & 350 & 750 & NGNP & 1 & Yes & Rankine & Vendor \\
\hline 3 & 600 & 800 & FOAK & 4 & No & Brayton & INL Model \\
\hline 4 & & 850 & NOAK & & & & \\
\hline 5 & & 900 & & & & & \\
\hline 6 & & 950 & & & & & \\
\hline 7 & \multicolumn{3}{|c|}{ Index from Drop-Down Selection } & & & & \\
\hline 8 & 2 & 3 & 3 & 2 & 1 & 1 & 1 \\
\hline 9 & \multicolumn{2}{|c|}{ Value Selected } & & & & & \\
\hline 10 & 600 & 850 & NOAK & 4 & Yes & Rankine & Vendor \\
\hline \multicolumn{8}{|l|}{11} \\
\hline 12 & \multicolumn{2}{|c|}{ User Inputs for Cost Basis: } & & & & & \\
\hline 13 & \multicolumn{2}{|l|}{ Analysis Year } & 2009 & & & & \\
\hline 14 & \multicolumn{2}{|l|}{ Inflation Rate } & $3 \%$ & & & & \\
\hline 15 & \multicolumn{2}{|c|}{ Analysis Year CEPCI } & 521.9 & & & & \\
\hline
\end{tabular}

Figure 5. List Info worksheet screenshot.

\subsubsection{Named Cells/Ranges}

The following cells names have been assigned on the List Info worksheet:

- $\quad$ RSize - cell A10

- $\quad$ ROTSel - cell B10

- $\quad$ RPhase - cell C10

- Number - cell D10

- $\quad$ PCyc - cell E10

- CycChoice - cell F10

- $\quad$ Staff - cell G10

- CEPCIYEAR - cell C12

- $\quad$ IRT - cell C13

- CEPCI - cell C14 
The following named ranges have been assigned on the List Info worksheet (used in the combo box input range on the HTGR Cost Summary worksheet):

- Reactor Size - range A2:A3

- $\quad \mathrm{ROT}$ - range B2:B6

- $\quad$ Phase - range C2:C4

- $\quad$ ReactorQty - range D2:D3

- HeatorPower - range E2:E3

- $\quad$ PowerCycle - range F2:F3

- $\quad$ StaffPlan - range G2:G3

- $\quad$ RVariables - range A10:G10

\subsubsection{Worksheet Formatting}

Cells highlighted purple indicate user inputs, these include the cell for Analysis Year (C12), Inflation Rate (C13), and Analysis Year CEPCI (C14). Data validation limitations have been entered for the analysis year, such that the user must specify a whole number greater than or equal to 2009. Similarly, data validation limitations for the inflation rate have been entered such that the user must input a value between $1 \%$ and $5 \%$. Cells highlighted pink include IF statements, other Excel functions, or equations dependent upon user inputs.

To access the data validation information for a given cell, select the cell in question, select the 'Data' tab in the 'Ribbon', and click the 'Data Validation' button, next select the 'Data Validation' option from the drop down list. This brings up the 'Data Validation' window which includes the 'Validation criteria' in the 'Settings' tab.

\subsubsection{Worksheet Equations/IF Statements}

The following equations and IF statements are included in the List Info worksheet:

- $\quad \mathrm{D} 3=\mathrm{IF}(\mathrm{RPhase}=" \mathrm{NGNP} ", 1,4)-$ This equation sets the available number of reactors to 1 when the NGNP project phase is selected, as it was assumed the demonstration plant would only include a single reactor.

- F2=IF(PCyc="Yes","Rankine"," ") - This equation sets the power cycle type to Rankine when the power cycle present combo box is set to Yes.

- $\quad \mathrm{F} 3=\mathrm{IF}(\mathrm{PCyc}=$ "Yes","Brayton"," ") - This equation sets the power cycle type to Brayton when the power cycle present combo box is set to Yes.

- A10 to G10=INDEX(array, index) - This equation sets the value selected in row 10 for the named ranges and the corresponding combo box index.

\subsubsection{Worksheet Macros}

No Macros are included in the List Info worksheet. 


\subsection{HTGR Capital Cost Worksheet}

The HTGR Capital Cost worksheet calculates the total capital cost for the selected HTGR plant configuration, as well as includes the data used to calculate the capital costs. The results of the calculations are passed to the HTGR Cost Summary worksheet, see Section 3.1. Capital costs are the sum of preconstruction costs, direct costs, indirect costs, and project contingency. For a description of the references used to tabulate the data included in this worksheet refer to TEV-1196 (INL 2011). All costs are calculated in 2009 dollars. However, the model is developed such that the capital costs can be scaled from 2009 dollars using the CEPCI, as discussed in Section 3.2. Only the scaled values are passed to the HTGR Cost Summary worksheet. In the examples provided, the analysis year is assumed to be 2009; therefore, the scaled values are the same as the calculated values, i.e. 2009 dollars.

At the top of the HTGR Capital Cost worksheet the user inputs specified in the combo boxes on the HTGR Cost Summary worksheet are listed, as shown in Figure 6.

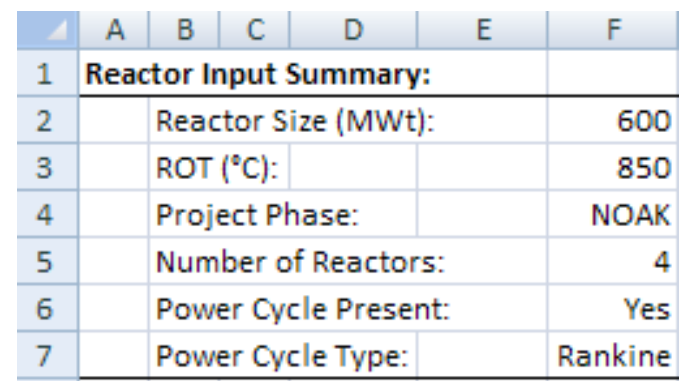

Figure 6. Reactor input summary on the HTGR Capital Cost worksheet, screenshot.

\subsubsection{Preconstruction Costs}

Preconstruction costs are the sum of the land and land rights costs and licensing and application costs. A single reactor is assumed to occupy 50 acres of land, while a four-pack is assumed to occupy 100 acres, per TEV-1196 (INL 2011). Licensing and application costs are specified for the NGNP, FOAK, and NOAK project phases for single and four-pack configurations. Preconstruction costs were assumed to be consistent for both $350 \mathrm{MWt}$ and $600 \mathrm{MWt}$ reactor sizes (INL 2011). Figure 7 presents a screenshot of the preconstruction costs section of the HTGR Capital Cost worksheet. Conditional formatting is used to highlight which licensing and application cost should apply to the selected configuration, i.e. the cell is highlighted green and corresponds to the value in cell I 24. 


\begin{tabular}{|c|c|c|c|c|c|c|c|c|c|c|c|c|c|}
\hline 4 & A & B & $\mathrm{C}$ & D & $E$ & $\mathrm{~F}$ & G & $\mathrm{H}$ & I & J & $\mathrm{K}$ & L & M \\
\hline 9 & \multicolumn{13}{|c|}{ PRECONSTRUCTION COSTS: } \\
\hline 10 & & & & & & & & & & & & & \\
\hline 11 & & \multicolumn{5}{|c|}{ Land and Land Rights (2009 \$): } & 100 & Acres & 10.00 & & & & \\
\hline 12 & & \multicolumn{5}{|c|}{ Land and Land Rights (2009 \$): } & & & 10.00 & & & & \\
\hline \multicolumn{14}{|l|}{13} \\
\hline 14 & & \multicolumn{5}{|c|}{ Licencing and Application Costs: } & & & & & & & \\
\hline 15 & & & & & & & \multicolumn{2}{|c|}{ Reactor Phase } & NGNP & \multicolumn{2}{|c|}{ FOAK } & \multicolumn{2}{|c|}{ NOAK } \\
\hline 16 & & & \multicolumn{3}{|c|}{ Description } & & \multicolumn{2}{|c|}{ Number of Units } & 1 & 1 & 4 & 1 & 4 \\
\hline 17 & & & \multicolumn{3}{|c|}{ Pre-Application } & & & & 30.00 & 15.00 & 15.00 & 15.00 & 15.00 \\
\hline 18 & & & \multicolumn{4}{|c|}{ ESP and COLA Preparation } & & & 69.00 & 23.00 & 28.00 & 23.00 & 28.00 \\
\hline 19 & & & \multicolumn{4}{|c|}{ ESP and COLA Review by NRC } & & & 108.00 & 25.00 & 25.00 & 12.00 & 12.00 \\
\hline 20 & & & \multicolumn{6}{|c|}{ Support of Construction \& Initial Operation } & 18.50 & 18.50 & 23.00 & 18.50 & 23.00 \\
\hline 21 & & & \multicolumn{4}{|c|}{ State and Local Permitting } & & & 3.00 & 3.00 & 3.00 & 3.00 & 3.00 \\
\hline 22 & & & \multicolumn{2}{|c|}{ Total } & & & & & 228.50 & 84.50 & 94.00 & 71.50 & 81.00 \\
\hline 23 & & & & & & & & & & & & & \\
\hline 24 & & \multicolumn{7}{|c|}{ Selected Configuration Licensing Costs (2009 \$): } & 81.00 & & & & \\
\hline 25 & & \multicolumn{7}{|c|}{ Selected Configuration Licensing Costs (2009 \$): } & 81.00 & & & & \\
\hline 26 & & & & & & & & & & & & & \\
\hline 27 & \multicolumn{7}{|c|}{ TOTAL PRECONSTRUCTION COSTS (2009 \$): } & & 91.00 & & & & \\
\hline 28 & \multicolumn{7}{|c|}{ TOTAL PRECONSTRUCTION COSTS (2009 \$): } & & 91.00 & & & & \\
\hline
\end{tabular}

Figure 7. Preconstruction costs on the HTGR Capital Cost worksheet, screenshot. 


\subsubsection{Direct Costs}

Direct costs are the sum of the individual estimates for the top capital cost items and the balance of equipment adder, assumed to be $25 \%$ of the sum of the individual estimates (INL 2011). The individual estimates are based on costs provided by Dominion Engineering, Inc. through a separate subcontract as documented in TEV-1196; cells highlighted in blue are scaled as described in the TEV (INL 2011). Figure 8 presents a screenshot of the direct costs section of the HTGR Capital Cost worksheet. Conditional formatting is used to highlight the sum of the individual estimates which should apply to the selected configuration, i.e. the cell is highlighted green, AE63, and corresponds to the value shown in cell I65. Conditional formatting is also used to hide the costs not associated with the selected power cycle, i.e. a Rankine cycle is selected for the example shown; hence, the rows corresponding to costs for the Brayton cycle are blank (rows 46, 47, 60, and 61).

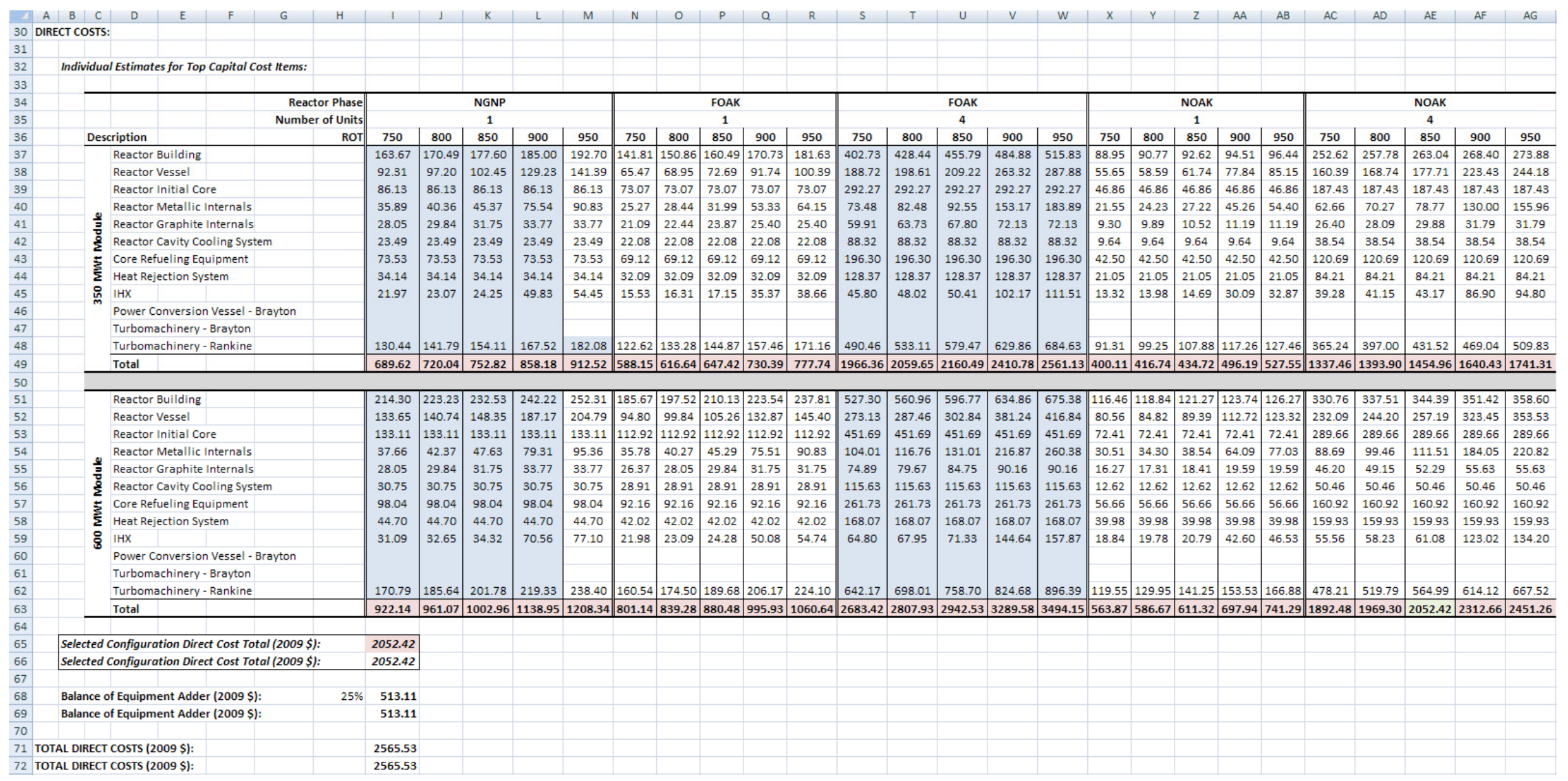

Figure 8. Direct costs on the HTGR Capital Cost worksheet, screenshot. 


\subsubsection{Indirect Costs and Total Overnight Capital Costs}

Indirect costs are the sum of design costs, construction services, home office and engineering services, field office and engineering services, and owner's costs. Design costs are the sum of conceptual design, preliminary design, final design, and research and development costs. The majority of design costs occur only for the NGNP project phase, only a fraction of the final design costs occur for the FOAK and NOAK project phases (INL 2011). Construction, home office and engineering services, field office and engineering services, and owner's costs are all assumed to be a fraction of the total direct costs: $20 \%$, $16 \%, 10 \%$, and $12 \%$, respectively (INL 2011). The base construction costs are the sum of preconstruction, direct, and indirect costs. A project contingency of $20 \%$ is assumed for all project phases (INL 2011). The total overnight cost is the sum of the base construction costs and the project contingency. Figure 9 presents a screenshot of the indirect costs and total overnight capital costs sections of the HTGR Capital Cost worksheet.

\subsubsection{Named Cells/Ranges}

No named cells or ranges are included in the HTGR Capital Cost worksheet.

\subsubsection{Worksheet Formatting}

Cells highlighted blue indicate individual cost estimate data that was scaled from other known data values. Cells highlighted pink include IF statements, other Excel functions, or equations dependent upon user inputs. Conditional formatting is used in row 22 which highlights the selected configuration licensing costs in green. Similarly, the selected configuration for the direct costs individual estimates (rows 29 and 63) is highlighted green according to the inputs specified by the user. Finally, conditional formatting is also used to hide the costs not associated with the selected power cycle configurations in the individual cost estimates (rows 46, 47, 48, 60, 61, and 62). To identify the conditional formatting used in any sheet, select the 'Home' tab on the 'Ribbon', select 'Conditional Formatting', and select 'Manage Rules' from the drop down list; this will list all conditional formatting on the given worksheet. 


\begin{tabular}{|c|c|c|c|c|c|c|c|c|}
\hline 4 & A & B & $\mathrm{C}$ & D & $\mathrm{E}$ & G & $\mathrm{H}$ & I \\
\hline 74 & \multicolumn{8}{|c|}{ INDIRECT COSTS: } \\
\hline 75 & & & & & & & & \\
\hline 76 & & \multicolumn{6}{|c|}{ Design Costs (NGNP Only - Excluding Final Design): } & \\
\hline 77 & & & \multicolumn{3}{|c|}{ Conceptual Design } & & & 0.00 \\
\hline 78 & & & \multicolumn{3}{|c|}{ Preliminary Design } & & & 0.00 \\
\hline 79 & & & \multicolumn{2}{|c|}{ Final Design } & & & & 20.00 \\
\hline 80 & & & \multicolumn{2}{|c|}{ R\&D } & & & & 0.00 \\
\hline 81 & & \multicolumn{4}{|c|}{ Total Design Costs (2009 \$): } & & & 20.00 \\
\hline 82 & & \multicolumn{4}{|c|}{ Total Design Costs (2009 \$): } & & & 20.00 \\
\hline 83 & & & & & & & & \\
\hline 84 & & \multicolumn{4}{|c|}{ Construction Services (2009 \$): } & & $20 \%$ & 514.11 \\
\hline 85 & & \multicolumn{4}{|c|}{ Construction Services (2009 \$): } & & & 514.11 \\
\hline 86 & & & & & & & & \\
\hline 87 & & \multicolumn{5}{|c|}{ Home Office and Engineering Services (2009 \$): } & $16 \%$ & 413.66 \\
\hline 88 & & \multicolumn{5}{|c|}{ Home Office and Engineering Services (2009 \$): } & & 413.66 \\
\hline 89 & & & & & & & & \\
\hline 90 & & \multicolumn{5}{|c|}{ Field Office and Engineering Services (2009 \$): } & $10 \%$ & 250.69 \\
\hline 91 & & \multicolumn{5}{|c|}{ Field Office and Engineering Services (2009 \$): } & & 250.69 \\
\hline 92 & & & & & & & & \\
\hline 93 & & \multicolumn{4}{|c|}{ Owner's Costs (2009 \$): } & & $12 \%$ & 295.75 \\
\hline 94 & & \multicolumn{4}{|c|}{ Owner's Costs (2009 \$): } & & & 295.75 \\
\hline 95 & & & & & & & & \\
\hline 96 & \multicolumn{5}{|c|}{ TOTAL INDIRECT COSTS (2009 \$): } & & & 1494.20 \\
\hline 97 & \multicolumn{5}{|c|}{ TOTAL INDIRECT COSTS (2009 \$): } & & & 1494.20 \\
\hline 98 & & & & & & & & \\
\hline 99 & \multicolumn{5}{|c|}{ BASE CONSTRUCTION COST (2009 \$): } & & & 4150.73 \\
\hline 100 & \multicolumn{5}{|c|}{ BASE CONSTRUCTION COST (2009 \$): } & & & 4150.73 \\
\hline \multicolumn{9}{|l|}{101} \\
\hline 102 & \multicolumn{5}{|c|}{ PROJECT CONTINGENCY (2009 \$): } & & $20 \%$ & 830.15 \\
\hline 103 & \multicolumn{5}{|c|}{ PROJECT CONTINGENCY (2009 \$): } & & & 830.15 \\
\hline 104 & & & & & & & & \\
\hline 105 & \multicolumn{5}{|c|}{ TOTAL OVERNIGHT COST (2009 \$): } & & & 4980.88 \\
\hline 106 & \multicolumn{5}{|c|}{ OVERNIGHT COST PER kWt (2009 \$): } & & & 2075.37 \\
\hline \multicolumn{9}{|l|}{107} \\
\hline 108 & TOT & AL O & VERN & HT $\cos$ & $(2009$ \$): & & & 4980.88 \\
\hline 109 & OVE & RNIC & IHT CC & T PER k & t (2009 \$): & & & 2075.37 \\
\hline
\end{tabular}

Figure 9. Indirect and total overnight costs on the HTGR Capital Cost worksheet, screenshot.

\subsubsection{Worksheet Equations/IF Statements}

In the preconstruction costs section of the HTGR Capital Cost worksheet, the following equation is used to set the acreage for the selected reactor configuration:

$$
\mathrm{G} 11=\mathrm{IF}(\mathrm{Number}=1,50, \mathrm{IF}(\mathrm{Number}=4,100,))
$$

Based on the above equation, if the user selects a single reactor cell G11 will display 50 acres, and if the user selects a four-pack configuration the cell will display 100 acres. Licensing and application costs are 
also presented for multiple reactor configurations, as a result, an IF statement is used in cell I24 which selects the appropriate value from row 22 as follows:

$$
\begin{aligned}
& \text { I24=IF(RPhase="NGNP",I22,IF(RPhase="FOAK",IF(Number=1,J22,IF(Number=4,K22,)), } \\
& \text { IF(RPhase="NOAK",IF(Number=1,L22,IF(Number=4,M22,))))) }
\end{aligned}
$$

The above function sets the selected configuration licensing costs to the appropriate licensing and application costs based on the values selected by the user on the HTGR Cost Summary worksheet.

In the direct costs, individual estimates section, only FOAK cost data for a single reactor was provided in the Dominion estimate; as a result the FOAK four-pack data was scaled based on the relationship between the NOAK single and four-pack configurations (INL 2011). The following example is provided for calculating the reactor vessel cost for a four-pack of 600 MWt HTGRs, for a FOAK project phase, for an ROT of $850^{\circ} \mathrm{C}$ (cell T52). The following Excel function is entered:

\section{$\mathrm{T} 52=\mathrm{AD} 52 / \mathrm{Y} 52 * \mathrm{O} 52$}

where cell AD52 is the reactor vessel cost for an NOAK four-pack $600 \mathrm{MWt}$ configuration at $850^{\circ} \mathrm{C}$, cell Y52 is the reactor vessel cost for an NOAK single $600 \mathrm{MWt}$ HTGR at $850^{\circ} \mathrm{C}$, and cell $\mathrm{O} 52$ is the reactor vessel cost for an FOAK single $600 \mathrm{MWt} \mathrm{HTGR} \mathrm{at} 850^{\circ} \mathrm{C}$. Similar equations can be found for all FOAK four-pack costs for both $600 \mathrm{MWt}$ and $350 \mathrm{MWt}$ modules.

Item costs were also scaled to determine the costs for the NGNP project phase for all ROTs except $950^{\circ} \mathrm{C}$, which was provided in the estimate from Dominion. Costs for the other ROTs were scaled based the average scaling factor for a single reactor for the FOAK and NOAK phases. For example, the reactor vessel cost for a single $600 \mathrm{MWt} \mathrm{HTGR}$ at $850^{\circ} \mathrm{C}$ ROT was calculated as follows:

\section{K52=AVERAGE(P52/Q52,Z52/AA52)*L52}

This equation multiples the scaled $900^{\circ} \mathrm{C}$ ROT NGNP cost by the average ratios for the $900^{\circ} \mathrm{C}$ and $850^{\circ} \mathrm{C}$ ROTs for the single FOAK and NOAK project phases.

The total costs for the individual estimates for top capital cost items are summed based on the power cycle selected by the user on the HTGR Cost Summary sheet. The following function is entered into cell AE63, the total cost for a NOAK, $600 \mathrm{MWt}$ four-pack, for an ROT of $850^{\circ} \mathrm{C}$ :

\section{AE63=SUM(AE51:AE59,IF(PCyc="yes",IF(CycChoice="Brayton",AE60:AE61,IF(CycChoice= "Rankine",AE62,))),}

This equation sums the individual item costs, excluding the power cycle components, and then depending upon if a power cycle is indicated by the user, the corresponding cycle costs, either Brayton or Rankine, selected by the user are added. The cycle selection also corresponds to the conditional formatting described in the section above, i.e. the example shown a Rankine cycle is selected; hence, the Brayton cycle parameters are hidden and not included in the summation.

Since the individual item direct costs are presented for multiple reactor configurations a lookup function is used in cell I65 which selects the appropriate value from either row 49 or 63 :

I65=HLOOKUP(ROTSel,IF(RPhase="NGNP",I36:M63,IF(RPhase="FOAK",IF(Number=1,N36: R63,IF(Number=4,S36:W63,)),IF(RPhase="NOAK",IF(Number=1,X36:AB63,IF(Number=4, AC36:AG63,))))),IF(RSize=350,14,IF(RSize=600,28,)), TRUE)

The above function uses the built in HLOOKUP function in Excel (horizontal lookup, i.e. looking across rows in an array) to select the appropriate value corresponding to the selected ROT; corresponding to the array for a single NGNP configuration, a single or four-pack FOAK configuration, or single or four-pack 
NOAK configuration; from either row 49 or 63 depending upon the reactor size selected [IF(RSize $=350$, $14, \operatorname{IF}(\operatorname{RSize}=600,28)$,$) , tells the function to select a value from array row 14$ or 28$)$. In the example provided, the lookup function selects the value in cell AE63 based on the function above and the user inputs selected on the HTGR Cost summary worksheet, as the selected configuration direct cost total shown in cell I65.

IF statements used in the indirect cost section of the HTGR Capital Cost worksheet are limited to calculation of design costs, based on the selected project phase. The following equations are used for the corresponding design costs:

- $\quad$ Conceptual design $-\mathrm{I} 77=\mathrm{IF}(\mathrm{RPhase}=" \mathrm{NGNP} ", 84,0)$

- $\quad$ Preliminary design $-\mathrm{I78}=\mathrm{IF}($ RPhase="NGNP",182,0)

- $\quad$ Final design $-\mathrm{I79}=\mathrm{IF}(\mathrm{RPhase}=$ "NGNP",296,20)

- $\quad \mathrm{R} \& \mathrm{D}-\mathrm{I} 80=\mathrm{IF}(\mathrm{RPhase}=" \mathrm{NGNP} ", 452,0)$

These equations set the design cost values for the NGNP project phase to the values described in TEV-1196, when the user sets the project phase to NGNP, otherwise all design costs are zero, except final design which has a cost of 20 (INL 2011).

The total overnight cost, presented in millions of dollars (cells I106 and I109), is converted to dollars per kWt using the following equation (only cell I106 is shown):

I106 $=\mathrm{I} 105^{*} 1000000 /\left(\mathrm{RSize}^{*} 1000 *\right.$ Number $)$

\subsubsection{Worksheet Macros}

No Macros are included in the HTGR Capital Cost worksheet.

\subsection{O\&Ms Worksheet}

The O\&Ms worksheet calculates O\&M costs for the selected HTGR plant configuration. The results of the calculations are passed to the HTGR Cost Summary worksheet, see Section 3.1. O\&M costs are the sum of payroll costs, various industry fees, insurance and taxes, material supplies services and upgrades, outage costs, and administration and general cost overhead (INL 2011). The worksheet includes the INL staffing estimate for a single and additional unit for both $600 \mathrm{MWt}$ and $350 \mathrm{MWt}$ plants, as outlined in TEV-1196 (INL 2011). A screenshot for the staffing plan is not included, as it identifies close to 200 positions and is prohibitively long, for the detailed staffing plans see TEV-1196 or the O\&Ms worksheet. Only the total plant staffing level for the INL analysis is presented in the screenshot for the O\&Ms worksheet. Additionally, the staffing levels identified in vendor estimates are presented; however, the breakdown by position is not included for the vendor estimate. Figure 10 presents a screenshot of the O\&Ms worksheet. All O\&M costs are presented in 2009 dollars; the inflation rate is used to adjust O\&M costs to years other than 2009, as outlined in Section 3.2. 


\begin{tabular}{|c|c|c|c|c|c|c|c|c|}
\hline 4 & A & B & $\mathrm{C}$ & $\mathrm{E}$ & $\mathrm{F}$ & G & $\mathrm{H}$ & I \\
\hline 1 & & & & & \multicolumn{2}{|c|}{$600 \mathrm{MWt}$} & \multicolumn{2}{|c|}{$350 \mathrm{MWt}$} \\
\hline 2 & & & & & Single Unit & $\begin{array}{c}\text { Additional } \\
\text { Unit }\end{array}$ & Single Unit & $\begin{array}{c}\text { Additional } \\
\text { Unit }\end{array}$ \\
\hline 225 & \multicolumn{3}{|c|}{ TOTAL PLANT STAFF - INL Estimate } & & 382 & 71 & 382 & 71 \\
\hline 226 & \multicolumn{3}{|c|}{ TOTAL PLANT STAFF - Vendor Estimate } & & 165 & 25.3 & 165 & 25.3 \\
\hline \multicolumn{9}{|c|}{227} \\
\hline 228 & \multicolumn{3}{|c|}{ Payroll Estimate } & & & & & \\
\hline 229 & \multicolumn{3}{|r|}{ Total Plant Staff from Vendor Estimate } & & 165 & 25.3 & 165 & 25.3 \\
\hline 230 & \multicolumn{3}{|c|}{ Staff Salary } & $\$ 63,400$ & $10,461,000$ & $1,606,133$ & $10,461,000$ & $1,606,133$ \\
\hline 231 & \multicolumn{3}{|c|}{ Staff Overtime } & $7.5 \%$ & 784,575 & 120,460 & 784,575 & 120,460 \\
\hline 232 & \multicolumn{3}{|c|}{ Staff Retirement and Benefits } & $38.5 \%$ & $4,027,485$ & 618,361 & $4,027,485$ & 618,361 \\
\hline 233 & \multicolumn{3}{|c|}{ Staff Bonus and Incentives } & $8.0 \%$ & 836,880 & 128,491 & 836,880 & 128,491 \\
\hline 234 & \multicolumn{3}{|c|}{ Staff Payroll Tax } & $7.7 \%$ & 805,497 & 123,672 & 805,497 & 123,672 \\
\hline 235 & \multicolumn{3}{|c|}{ Total Staff Payroll } & & $16,915,437$ & $2,597,118$ & $16,915,437$ & $2,597,118$ \\
\hline 236 & \multicolumn{3}{|c|}{ Industry Fees: } & & & & & \\
\hline 237 & \multicolumn{3}{|c|}{ NRC Fees } & & $4,784,000$ & $4,784,000$ & $4,784,000$ & $4,784,000$ \\
\hline 238 & \multicolumn{3}{|c|}{ INPO Fees } & & 706,344 & 176,586 & 706,344 & 176,586 \\
\hline 239 & \multicolumn{3}{|c|}{ NEI Fees } & & 59,366 & 59,366 & 34,630 & 34,630 \\
\hline 240 & \multicolumn{3}{|c|}{ Other Costs: } & & & & & \\
\hline 241 & \multicolumn{3}{|c|}{ Insurance and Taxes } & & $3,000,000$ & $1,000,000$ & $3,000,000$ & $1,000,000$ \\
\hline 242 & \multicolumn{4}{|c|}{ Material Supplies Services and Upgrades } & $5,000,000$ & $5,000,000$ & $3,000,000$ & $3,000,000$ \\
\hline 243 & \multicolumn{3}{|c|}{ Outage O\&M } & & $4,070,724$ & $4,070,724$ & $2,945,925$ & $2,945,925$ \\
\hline 244 & \multicolumn{4}{|c|}{ Administration and General Cost Overhead } & $3,000,000$ & $3,000,000$ & $3,000,000$ & $3,000,000$ \\
\hline 245 & \multicolumn{4}{|c|}{ Total O\&M (2009\$) } & $37,535,870$ & $20,687,793$ & $34,386,336$ & $17,538,259$ \\
\hline 246 & \multicolumn{4}{|c|}{ Total O\&M (2009 \$) } & $37,535,870$ & $20,687,793$ & $34,386,336$ & $17,538,259$ \\
\hline 247 & & & & & & & & \\
\hline 248 & \multicolumn{3}{|c|}{ Selected O\&M Costs (Million $2009 \$$ ) } & & 99.60 & & & \\
\hline 249 & \multicolumn{3}{|c|}{ Selected O\&M Cost Per MWt-hr (2009\$) } & & 4.74 & \$/MWt-hr & & \\
\hline
\end{tabular}

Figure 10. O\&Ms worksheet screenshot.

\subsubsection{Named Cells/Ranges}

No named cells or ranges are included in the O\&Ms worksheet.

\subsubsection{Worksheet Formatting}

Cells highlighted pink include IF statements, other Excel functions, or equations dependent upon user inputs. Conditional formatting is used in rows 245 and 246, which highlights the costs used in the O\&M calculations in green. To identify the conditional formatting used in any sheet, select the 'Home' tab on the 'Ribbon', select 'Conditional Formatting', and select 'Manage Rules' from the drop down list; this will list all conditional formatting on the given worksheet.

\subsubsection{Worksheet Equations/IF Statements}

In the O\&Ms worksheet, the following equation is used to set the staffing estimate based on the user selection in the HTGR Cost Summary worksheet, cell F229 is used as the example:

$$
\text { F229=IF(Staff="Vendor",F226,IF(Staff="INL Model",F225,)) }
$$


This equation sets the cell value (row 229) to either the INL or vendor staffing estimate (row 225 or 226, respectively) based on the value selected by the user. The selected O\&M cost is calculated by the following equation in cell F248:

$$
\begin{aligned}
& \text { F248 }=(\mathrm{IF}(\mathrm{RSize}=600, \mathrm{~F} 246, \mathrm{IF}(\mathrm{RSize}=350, \mathrm{H} 246,))+\mathrm{IF}(\text { Number }=4, \mathrm{IF}(\mathrm{RSize}=600,(3 * \mathrm{G} 246), \\
& \quad \operatorname{IF}(\mathrm{RSize}=350,(3 * \mathrm{I} 246),)))) / 1000000
\end{aligned}
$$

This equation selects either the $600 \mathrm{MWt}$ or $350 \mathrm{MWt}$ costs for the single reactor, then adds three times the appropriate additional unit costs if a four-pack is selected. Finally, the O\&M cost per MWt-hr is calculated using the following equation:

$$
\text { F249=F248*1000000/(RSize*Number)/(365*24) }
$$

It is assumed that O\&M costs are consistent for all project phases (INL 2011).

\subsubsection{Worksheet Macros}

No Macros are included in the O\&Ms worksheet.

\subsection{Yearly Fuel Cost Worksheet}

The Yearly Fuel Cost worksheet calculates fuel costs for the selected HTGR plant configuration. The results of the calculations are passed to the HTGR Cost Summary worksheet, see Section 3.1. Fuel costs are the sum of uranium ore, uranium conversion, uranium enrichment, tails disposal, fuel fabrication, on-site spent fuel storage, and spent fuel disposition costs (INL 2011). The number of fuel blocks per reload is dependent upon the size and number of reactors in the selected configuration, as is the kilograms of heavy metals in the refueling blocks (INL 2011). The calculations for the amount of uranium, $\mathrm{U}_{3} \mathrm{O}_{8}$, and separative work units (SWU) are detailed in TEV-1196; however, they will also be summarized in this document (INL 2011). Figure 11 presents a screenshot of the Yearly Fuel Cost worksheet. All fuel costs are presented in 2009 dollars; the inflation rate is used to adjust fuel costs to years other than 2009, as outlined in Section 3.2.

\subsubsection{Named Cells/Ranges}

No named cells or ranges are included in the Yearly Fuel Cost worksheet.

\subsubsection{Worksheet Formatting}

Cells highlighted pink include IF statements, other Excel functions, or equations dependent upon user inputs. 


\begin{tabular}{|c|c|c|c|c|}
\hline 4 & A & B & $\mathrm{C}$ & D \\
\hline 1 & Description & Value & & \\
\hline 2 & Fuel Blocks in Reload & 2040 & & \\
\hline 3 & Uranium Loading & 4.4 & & \\
\hline 4 & Enrichment & $15 \%$ & & \\
\hline 5 & Fuel Cycle Length, months & 18 & & \\
\hline 6 & Reload Blocks per Year & 0.66667 & & \\
\hline 7 & Uranium in Tailings & $0.20 \%$ & & \\
\hline 8 & U235 Percentage & $0.72 \%$ & & \\
\hline 9 & Heavy Metals in Refueling Blocks, kg & 9048 & & \\
\hline 10 & Uranium Product per Year, kg & 5984 & & \\
\hline 11 & Uranium Feed per Year, kg & 171634 & & \\
\hline 12 & Uranium in U308 & $85 \%$ & & \\
\hline 13 & U308 Required per Year, kg & 202403 & & \\
\hline 14 & Uranium Tailings per Year, $\mathrm{kg}$ & 165650 & & \\
\hline 15 & SWU & 197881 & & \\
\hline 16 & & & & \\
\hline 17 & Item & & Unit Cost & Yearly Cost $-\$$ \\
\hline 18 & Uranium Ore & 106 & $\$$ per kg U308 & $21,472,961$ \\
\hline 19 & Uranium Conversion & 11 & $\$$ per kg Uranium Feed & $1,820,866$ \\
\hline 20 & Uranium Enrichment & 122 & $\$$ per SWU & $24,142,134$ \\
\hline 21 & Tails Disposal & 11 & $\$$ per kg Uranium Tailings & $1,757,382$ \\
\hline 22 & NGNP Fuel Fab Cost & 10,609 & $\$$ per kg Uranium Product & $63,484,256$ \\
\hline 23 & On-Site Spent Fuel Storage & 223 & $\$$ per kg Heavy Metals & $1,343,863$ \\
\hline 24 & Spent Fuel Disposition & 3,293 & $\$$ per kg Heavy Metals & $19,861,446$ \\
\hline 25 & Total $(2009 \$)$ & & & $133,882,908$ \\
\hline 26 & \multicolumn{3}{|c|}{ Refueling Cost Per Core, for Full 18 Month Fuel Cycle (2009\$) } & $50,206,091$ \\
\hline 27 & Total $(2009 \$)$ & & & $133,882,908$ \\
\hline 28 & Total (Million $2009 \$$ ) & & & 133.88 \\
\hline 29 & \multicolumn{3}{|c|}{ Refueling Cost Per Core, for Full 18 Month Fuel Cycle (2009\$) } & $50,206,091$ \\
\hline 30 & \multicolumn{3}{|c|}{ Refueling Cost Per Core, for Full 18 Month Fuel Cycle (Million $2009 \$$ ) } & 50.21 \\
\hline 31 & \multicolumn{3}{|l|}{ Fuel Cost Per MWt-hr (2009 \$/MWt-hr) } & 6.37 \\
\hline
\end{tabular}

Figure 11. Yearly Fuel Cost worksheet screenshot.

\subsubsection{Worksheet Equations/IF Statements}

Data and specific references for the equations described in this section are presented in TEV-1196; please refer to that document for detailed information on the following calculations (INL 2011). In the Yearly Fuel Cost worksheet, the following equation is used to calculate the number of fuel blocks in each fuel reloading:

\section{B2 $=510 *$ RSize $/ 600 *$ Number}

The mass of heavy metals, in the refueling blocks, is calculated as follows:

B9 $=(1748+514) *$ RSize $/ 600 *$ Number 
The mass of uranium fed per year is next calculated based on the following equation (see page 40 of INL 2011):

$\mathrm{B} 11=\mathrm{B} 10 *(\mathrm{~B} 4-\mathrm{B} 7) /(\mathrm{B} 8-\mathrm{B} 7)$

The amount of uranium tailings per year is then calculated (see page 40 of INL 2011):

$$
\mathrm{B} 14=\mathrm{B} 10 *(\mathrm{~B} 4-\mathrm{B} 8) /(\mathrm{B} 8-\mathrm{B} 7)
$$

Finally, the SWUs are calculated (see page 40 of INL 2011):

$$
\begin{aligned}
& \mathrm{B} 15=\mathrm{B} 10 *(1-2 * \mathrm{~B} 4) * \mathrm{LN}((1-\mathrm{B} 4) / \mathrm{B} 4)+\mathrm{B} 14 *(1-2 * \mathrm{~B} 7) * \mathrm{LN}((1-\mathrm{B} 7) / \mathrm{B} 7)-\mathrm{B} 11 *(1-2 * \mathrm{~B} 8) * \\
& \mathrm{LN}((1-\mathrm{B} 8) / \mathrm{B} 8)
\end{aligned}
$$

The above calculations provide the fuel requirements to calculate the yearly costs that make up the total annual refueling costs and the refueling cost per core. The majority of costs are consistent for all project phases, excluding fuel fabrication costs, for which costs are higher for the NGNP and FOAK project phases. The fuel fabrication unit cost is defined as follows:

$$
\begin{aligned}
& \text { B22 }=\text { IF }(\text { OR }(\text { RPhase }=" N G N P ", \text { RPhase }=" F O A K "), 25000, \text { IF }(\text { RPhase }=" N O A K ", 10000,))^{*} \\
& \quad(1+\mathrm{IRT})^{\wedge}(2009-2007)
\end{aligned}
$$

The fuel fabrication cost is based on 2007 values; thus, the costs are adjusted to 2009 values using the inflation rate specified in the List Info worksheet. Yearly costs (column D) are calculated by multiplying the unit cost by the annual yearly requirement (column B). The total cost is the sum of all the yearly costs, and the cost per core is calculated as follows:

B26=D25/Number/B6

Finally, the fuel cost per MWt-hr is calculated using the following equation:

B31=D28*1000000/(RSize*Number)/(365*24)

\subsubsection{Worksheet Macros}

No Macros are included in the Yearly Fuel Cost worksheet.

\subsection{Decommissioning Worksheet}

The Decommissioning worksheet calculates decommissioning costs for the selected HTGR plant configuration. The results of the calculations are passed to the HTGR Cost Summary worksheet, see Section 3.1. Decommissioning costs were estimated based on the methodology presented in NUREG-1307, Rev. 14. As this document is for estimation of decommissioning costs for large light water reactors (LWRs), the decommissioning costs were converted to a dollar per MWt basis in order to estimate the costs for decommissioning the HTGR (INL 2011). Figure 12 presents a screenshot of the Decommissioning worksheet. All decommissioning costs are presented in 2009 dollars; the inflation rate is used to adjust fuel costs to years other than 2009, as outlined in Section 3.2. 


\begin{tabular}{|c|c|c|c|c|c|c|}
\hline 4 & A & B & $\mathrm{C}$ & D & E & $\mathrm{F}$ \\
\hline 1 & & PWR & BWR & Average & & \\
\hline 2 & $C_{1986}$ & 105 & 135 & 120 & & \\
\hline 3 & $\mathbf{E}$ & 2.139 & 2.181 & 2.10 & & \\
\hline \multicolumn{7}{|l|}{4} \\
\hline 5 & & Northeast & South & Midwest & West & Average \\
\hline 6 & $\mathbf{L}$ & 2.41 & 2.21 & 2.29 & 2.29 & 2.23 \\
\hline \multicolumn{7}{|l|}{7} \\
\hline 8 & & \multicolumn{2}{|c|}{ Direct Disposal } & \multicolumn{2}{|c|}{$\begin{array}{c}\text { Direct Disposal with } \\
\text { Vendors }\end{array}$} & \multirow[t]{2}{*}{ Average } \\
\hline 9 & & PWR & BWR & PWR & BWR & \\
\hline 10 & B & 27.292 & 24.356 & 12.28 & 12.54 & 18.543 \\
\hline \multicolumn{7}{|l|}{11} \\
\hline 12 & \multicolumn{3}{|c|}{ Calculated Decommissioning Cost: } & 696.25 & & \\
\hline 13 & MWt: & & & 3,400 & & \\
\hline \multicolumn{7}{|l|}{14} \\
\hline 15 & \multicolumn{2}{|c|}{ \$/MWt (2009 \$) } & & 204,780 & & \\
\hline 16 & \multicolumn{2}{|c|}{ \$/MWt (2009 \$) } & & 204,780 & & \\
\hline 17 & \multicolumn{3}{|c|}{ Total Decommissioning Cost (2009 \$) } & 491.47 & & \\
\hline
\end{tabular}

Figure 12. Decommissioning worksheet screenshot.

\subsubsection{Named Cells/Ranges}

No named cells or ranges are included in the Decommissioning worksheet.

\subsubsection{Worksheet Formatting}

Cells highlighted pink include IF statements, other Excel functions, or equations dependent upon user inputs.

\subsubsection{Worksheet Equations/IF Statements}

The decommissioning cost for an average light water reactor, as specified in NUREG-1307, was calculated using the following equation (see page 41 of INL 2011):

$$
\mathrm{D} 12=\mathrm{D} 2 *(0.65 * \mathrm{~F} 6+0.13 * \mathrm{D} 3+0.22 * \mathrm{~F} 10)
$$

The dollar per MWt for decommissioning is calculated based on a 3,400 MWt LWR. This average cost per MWt is used to calculate the total decommissioning cost as follows:

$$
\text { D17=D16*RSize*Number/1000000 }
$$

\subsubsection{Worksheet Macros}

No Macros are included in the Decommissioning worksheet.

\subsection{Full Results Worksheet}

The Full Results worksheet tabulates the results summarized on the HTGR Cost Summary worksheet for all possible configuration iterations, excluding the staffing plan, which is set equal to the current user selection. To populate the tables, click the Populate Tables for Selected Staffing Plan button. This button 
is linked to the FullResults Macro. A partial screenshot of the Full Results worksheet is shown in Figure 13. Note, all reactor sizes and phases are included on this sheet, not just the NGNP project phase as shown in the partial screenshot.

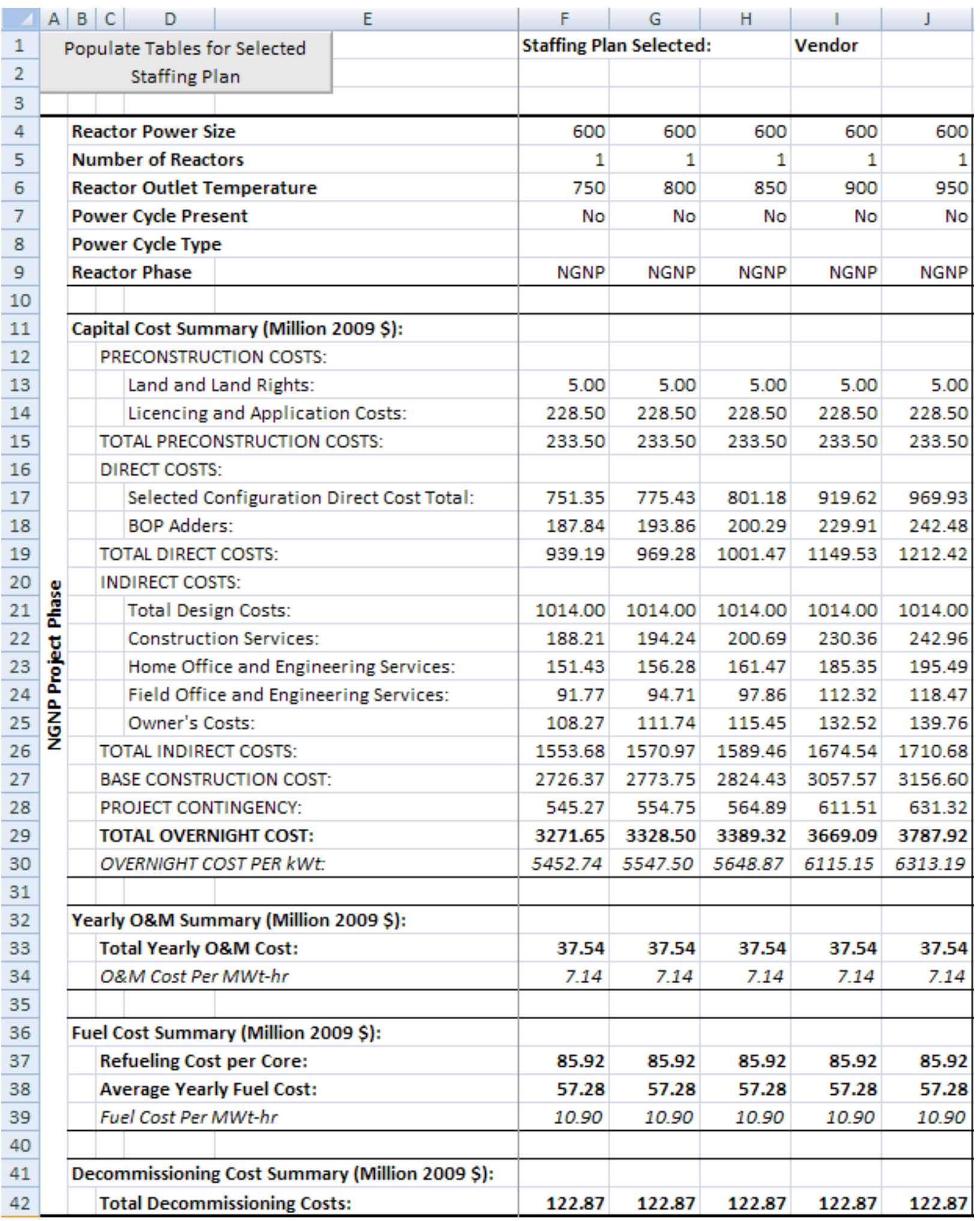

Figure 13. Full Results worksheet, partial screenshot. 


\subsubsection{Named Cells/Ranges}

No named cells or ranges are included in the Full Results worksheet.

\subsubsection{Worksheet Formatting}

No special formatting is used on the Full Results worksheet.

\subsubsection{Worksheet Equations/IF Statements}

No equations or IF statements are included in the Full Results worksheet.

\subsubsection{Worksheet Macros}

The FullResults Macro compiles the full results for the user selected staffing plan into several tables, when the user clicks the Populate Tables for Selected Staffing Plan button. The FullResults Macro is presented in Figure 14. Note this Macro is several pages long.

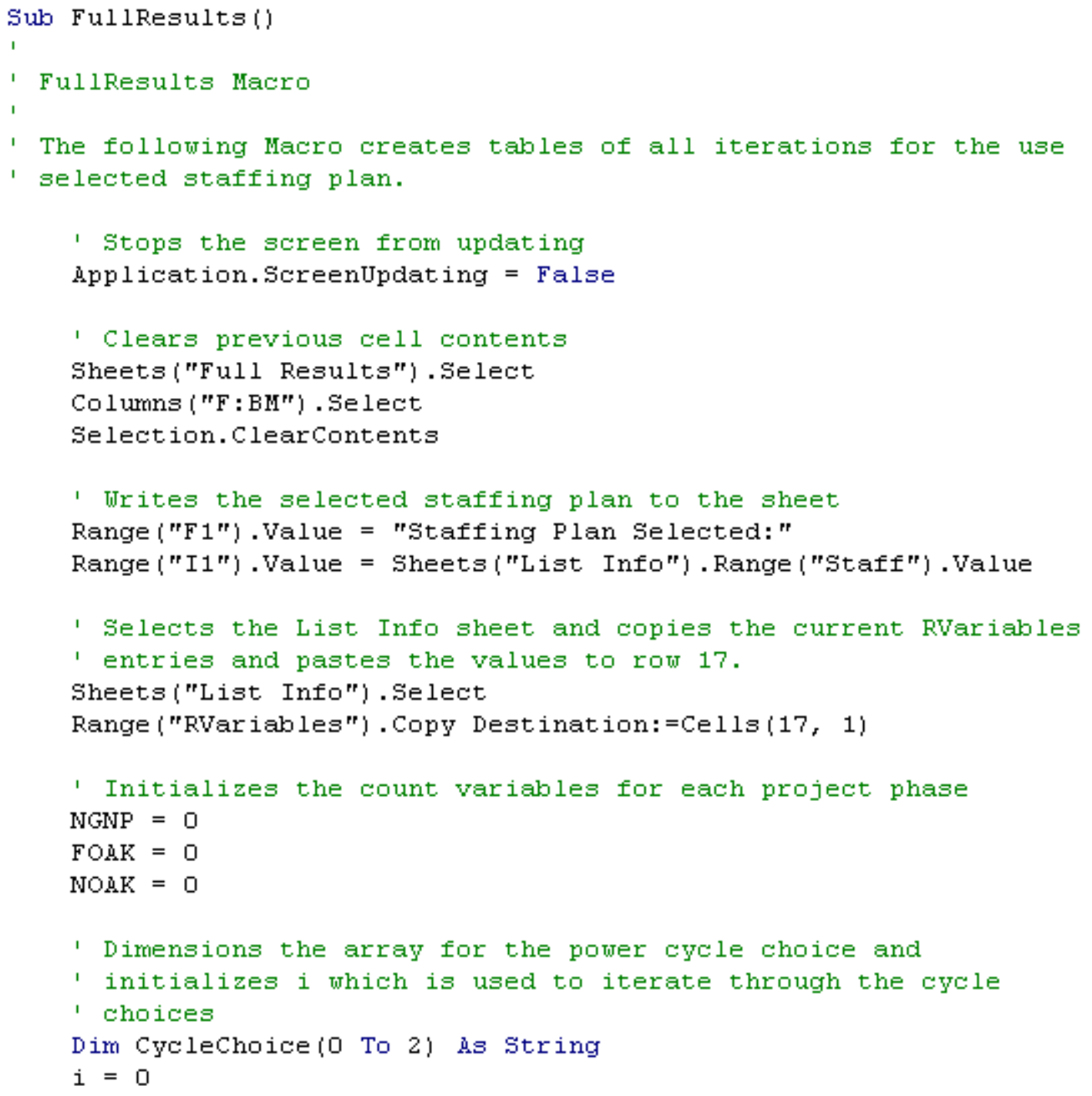

Figure 14. FullResults Macro. 


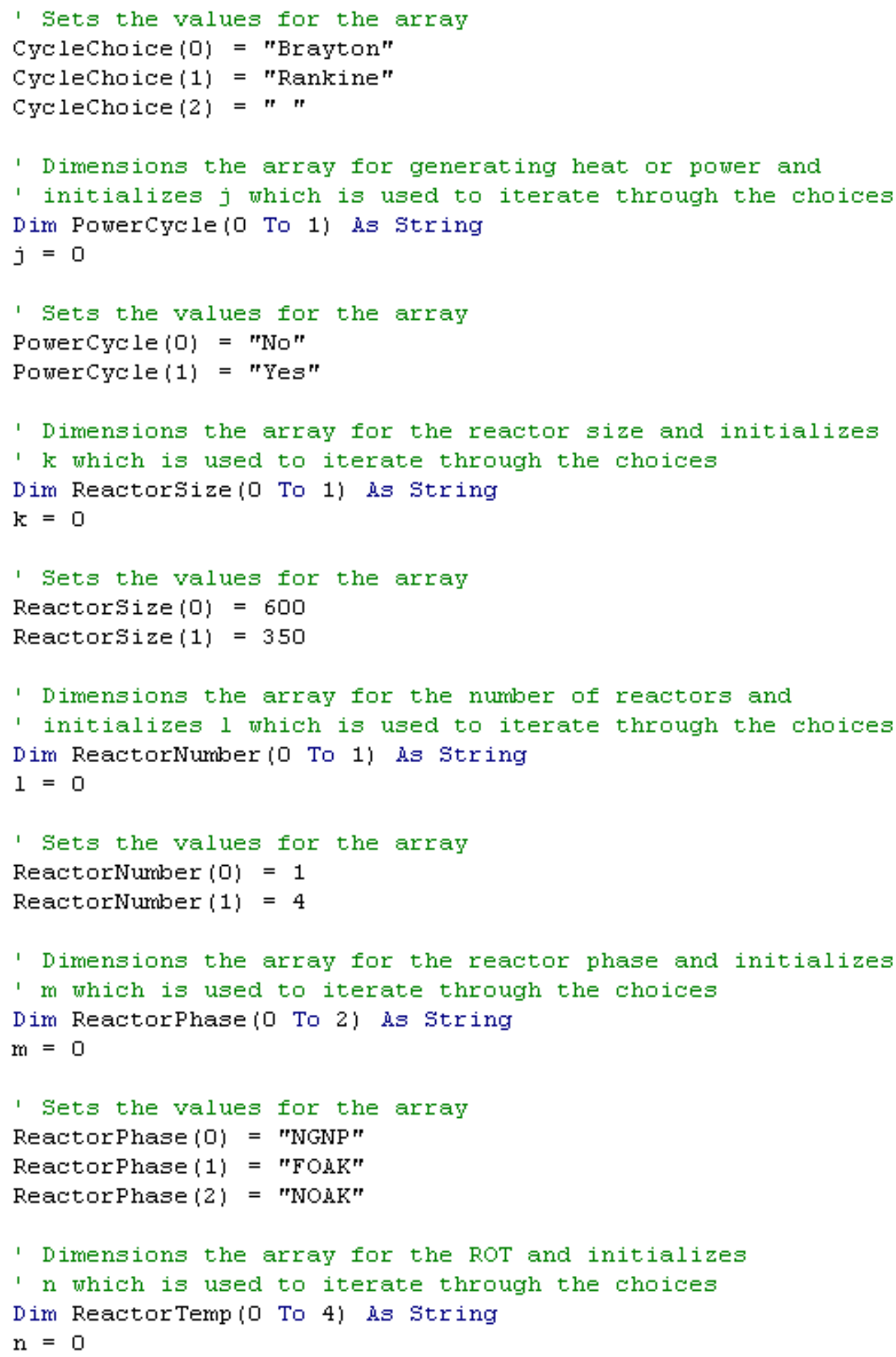

Figure 14. FullResults Macro. (continued) 


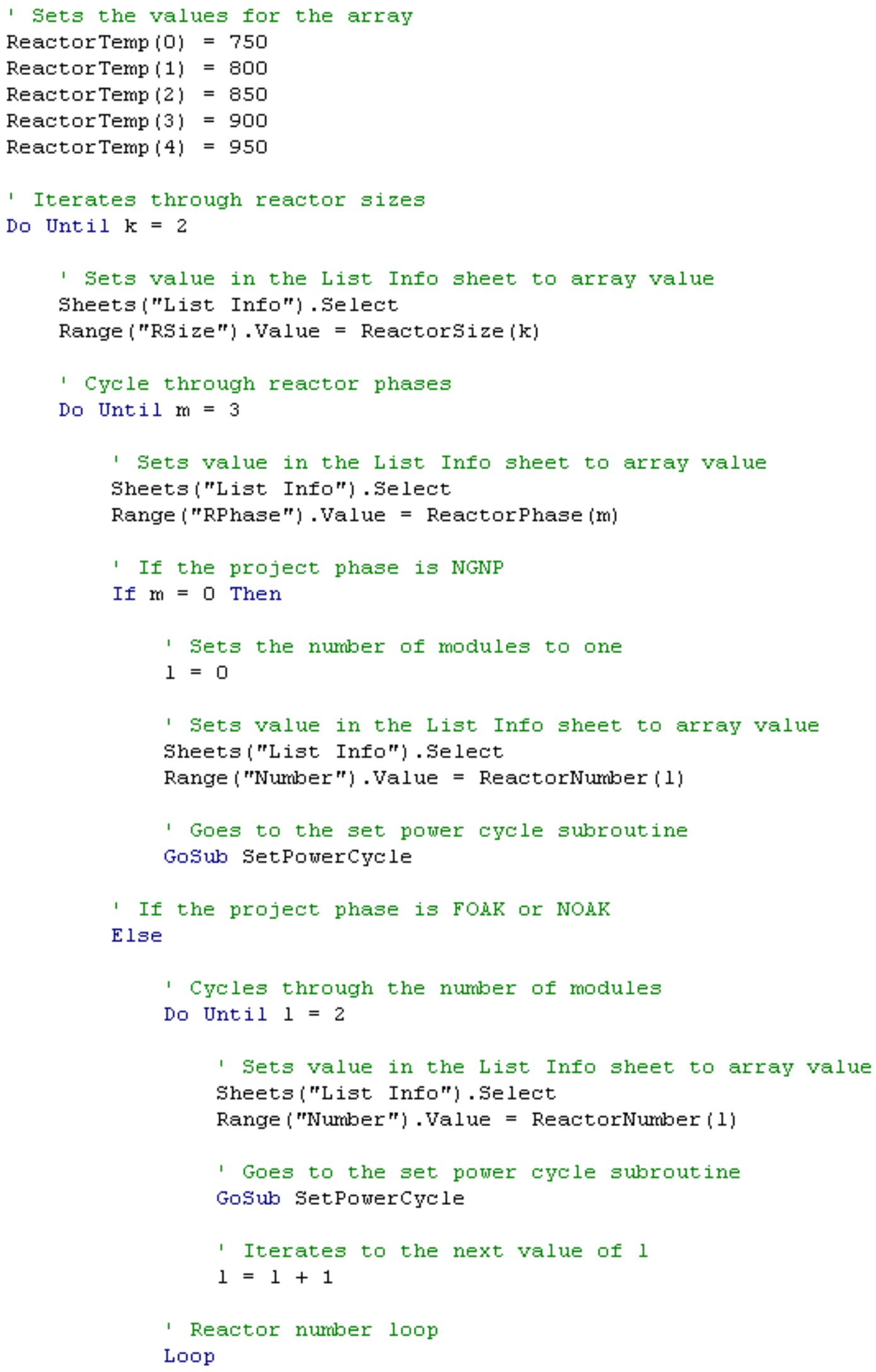

Figure 14. FullResults Macro. (continued) 


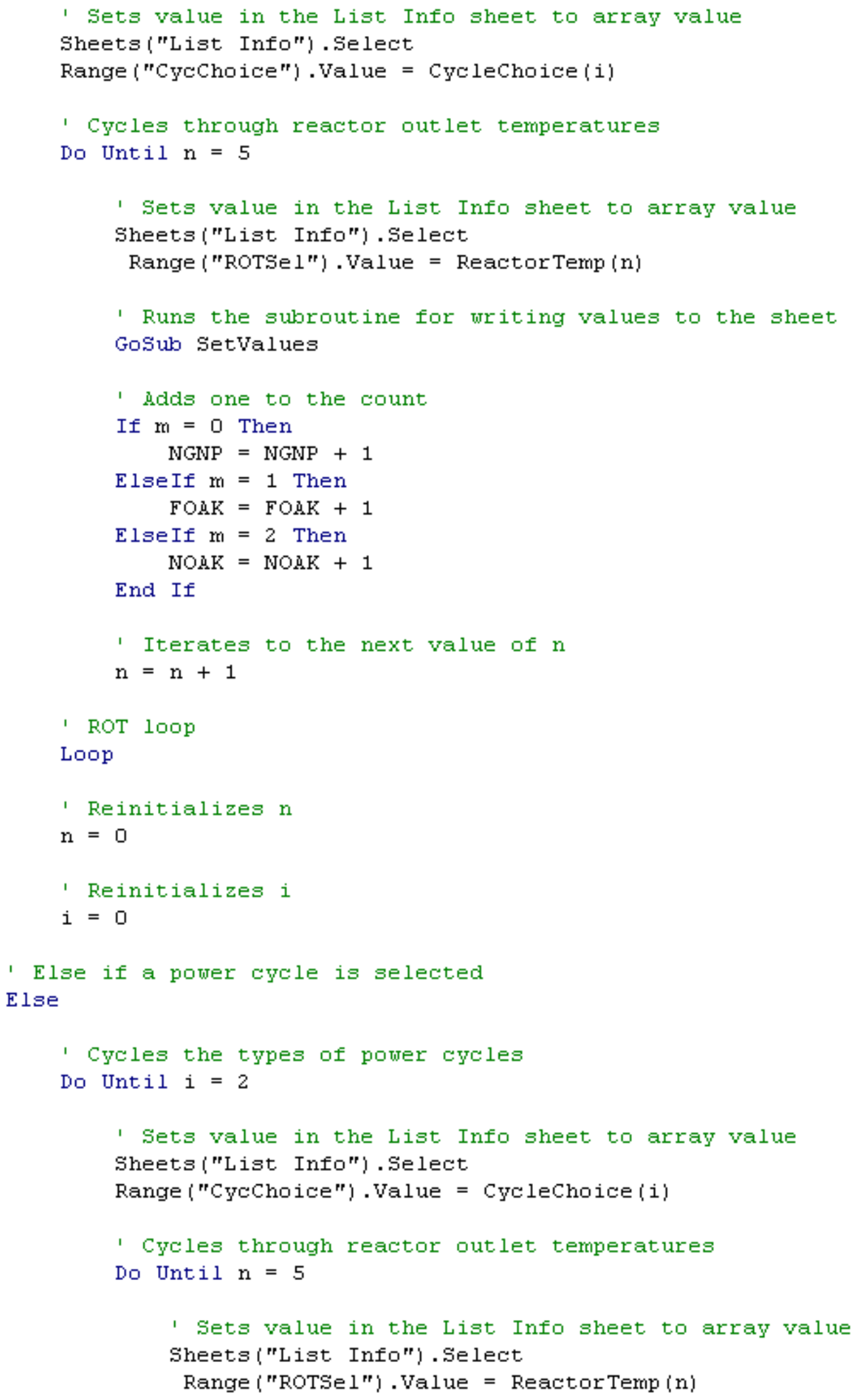

Figure 14. FullResults Macro. (continued) 


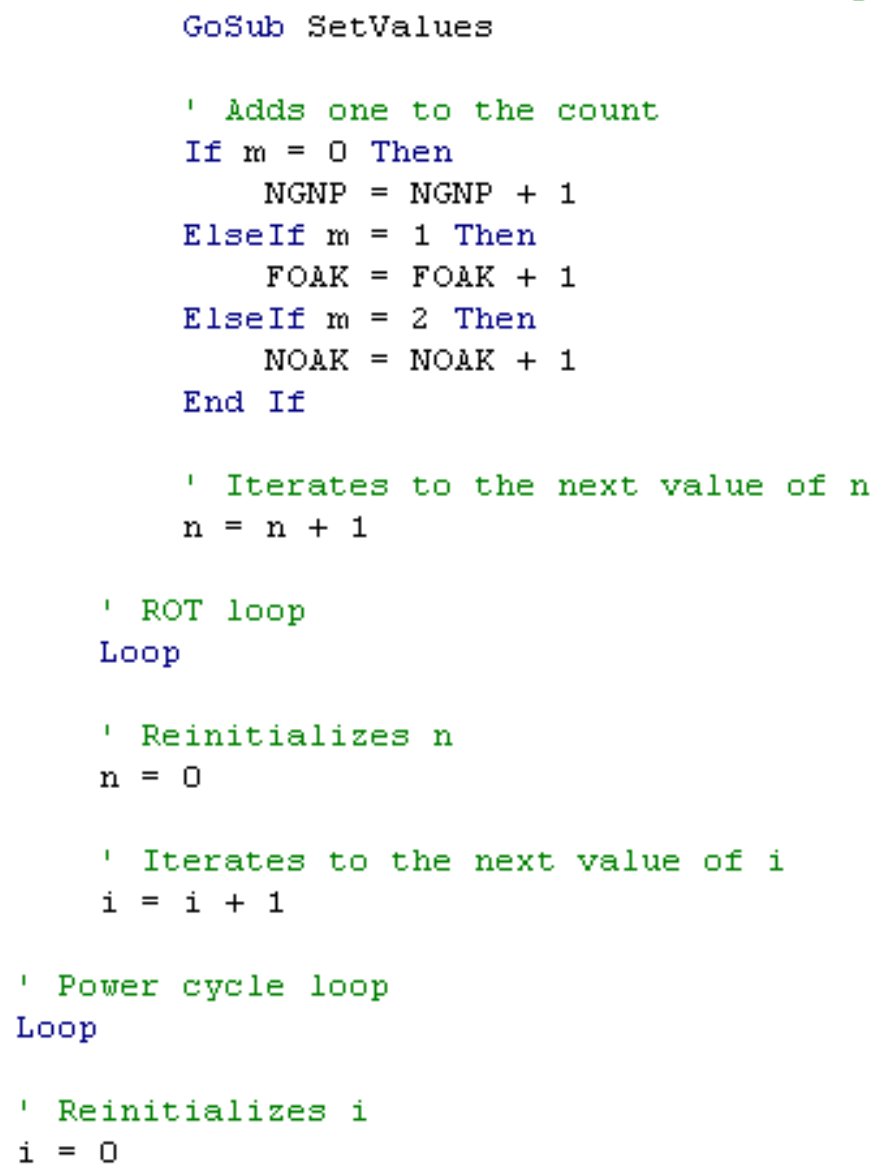

Figure 14. FullResults Macro. (continued) 


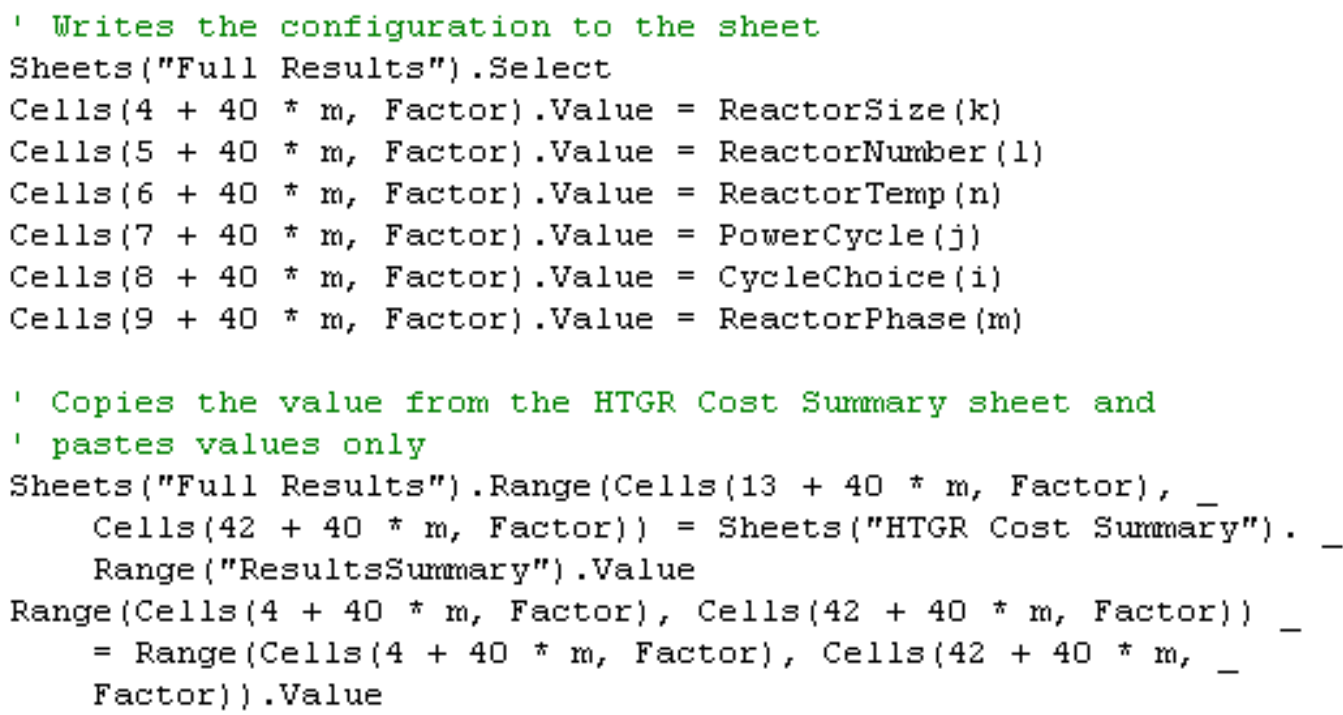

Figure 14. FullResults Macro. (continued)

\subsection{Correlations Worksheet}

The Correlations worksheet is used to develop relationships for the HTGR and power cycle costs based on the ROT, thermal rating, power cycle rating, number of modules, and project phase. These correlations were developed in order to scale the costs for project variations not included in HTGR Cost Model. For example, these correlations can be used to estimate the cost of six HTGR modules at an ROT of $775^{\circ} \mathrm{C}$ for an NOAK HTGR plant. Separate correlations are developed for the HTGR cost without power cycles (i.e. for heat production only), the Brayton cycle cost, and the Rankine cycle cost. The correlations are based on the direct costs, less the adders, which can be added to the correlations to account for the balance of equipment costs, indirect costs, preconstruction costs, and project contingency as described in TEV-1196 (INL 2011).

The totals for the HTGR less power cycle (rows 4 and14), the Brayton cycle (rows 7 and 17), and the Rankine cycle (rows 10 and 20) are determined based on the summation of the corresponding individual item costs on the HTGR Capital Cost worksheet. Based on this information, along with the assumed cycle efficiencies (rows 25 and 28), correlations were developed as described in TEV-1196 (INL 2011). The correlations are then used to predict the various direct costs (rows $5,8,11,15,18,21$ ) and the percent error between the model prediction and actual value is also calculated (rows 6, 9, 12, 16, 19, 22).

Figure 15 presents a screenshot of the Correlations worksheet. Charts comparing the correlations and predicted values are also included on this sheet; however, the screenshot does not include these charts. 


\begin{tabular}{|c|c|c|c|c|c|c|c|c|c|c|c|c|c|c|c|c|c|c|c|c|c|c|c|c|c|c|c|}
\hline$\Delta t$ & \multirow{2}{*}{\multicolumn{2}{|c|}{\begin{tabular}{c|c} 
B & C \\
\multicolumn{3}{|l|}{ Reactor Phase }
\end{tabular}}} & \multirow{2}{*}{\multicolumn{5}{|c|}{$\begin{array}{c}F \\
\text { NGNP }\end{array}$}} & \multirow{2}{*}{\multicolumn{5}{|c|}{$\begin{array}{l}K \\
\text { FOAK }\end{array}$}} & \multirow{3}{*}{\multicolumn{5}{|c|}{$\begin{array}{c}\text { P } \\
\text { FOAK } \\
4\end{array}$}} & \multirow{2}{*}{\multicolumn{5}{|c|}{ NOAK }} & $x$ & Y & $z$ & AA & $A B$ \\
\hline 1 & & & & & & & & & & & & & & & & & & & & & & & \multicolumn{5}{|c|}{ NOAK } \\
\hline 2 & \multirow{2}{*}{\multicolumn{2}{|c|}{ Number of Units }} & \multicolumn{5}{|c|}{1} & \multicolumn{5}{|c|}{1} & & & & & & \multicolumn{5}{|c|}{1} & \multicolumn{5}{|c|}{4} \\
\hline 3 & & & 750 & 800 & 850 & 900 & 950 & 750 & 800 & 850 & 900 & 950 & 750 & \multicolumn{3}{|c|}{4} & 950 & 750 & 800 & 850 & 900 & 950 & 750 & 800 & 850 & 900 & 950 \\
\hline 4 & \multirow{2}{*}{\multicolumn{2}{|c|}{$\begin{array}{l}\text { Total Less Power Cycle } \\
\text { Model Prediction }\end{array}$}} & |559.17| & 578.25 & 598.71 & 690.67 & 730.44 & 465.54 & 483.37 & $502.55^{\prime}$ & 572.93 & 606.58 & 1475.90 & $\mid 1526.54$ & \begin{tabular}{|l|l|}
1581.02 & 1 \\
\end{tabular} & |1780.93| & $1876.50 \mid$ & 308.80 & 317.49 & 326.84 & 378.93 & 400.09 & 972.22 & $996.90^{\circ}$ & 1023.441 & 1171.39 & 1231.48 \\
\hline 5 & & & 543.25 & 559.00 & $\mid 574.76$ & 665.87 & 702.56 & 459.41 & 472.73 & 486.05 & 563.10 & 594.13 & 1446.72 & $1488.67 \mid$ & $\mid 1530.63$ & 1773.26 | & |1870.98 & 308.96 & 317.92 & 326.88 & \begin{tabular}{|l|}
378.69 \\
\end{tabular} & 399.56 & 972.94 & 1001.15 & $|1029.37| 1$ & 1192.54 & 1258.26 \\
\hline 6 & \multirow{2}{*}{\multicolumn{2}{|c|}{$\sum \frac{\% \text { Error }}{\text { Total Brayton Cycle }}$}} & 2.85 & 3.33 & 4.00 & 3.59 & 3.82 & 1.32 & 2.20 & 3.28 & 1.72 & 2.05 & 1.98 & \begin{tabular}{|l|}
2.48 \\
\end{tabular} & 3.19 & \begin{tabular}{|l|} 
\\
\end{tabular} .43 & 0.29 & 0.05 & 0.13 & 0.01 & 0.06 & 0.13 & 0.07 & 0.43 & 0.58 & 1.81 & 2.17 \\
\hline 7 & & & 279.81 & 301.83 & 325.71 & 367.45 & 400.13 & 247.17 & 267.03 & $288.59^{\prime}$ & 323.23 & 351.86 & \begin{tabular}{|l|l|}
933.87 \\
\end{tabular} & 1010.29 & 1093.251 & 1215.29 & 1322.31 & 118.10 & 126.97 & 136.59 & 156.52 & 170.56 & 425.85 & 458.79 & 494.50 & 560.25 & 610.06 \\
\hline 8 & $\boldsymbol{\Sigma}_{0}$ Model Predictior & & 277.70 & 299.28 & 320.86 & 369.07 & 402.24 & 244.63 & \begin{tabular}{|l|}
263.64 \\
\end{tabular} & 282.64 & 325.11 & 354.32 & \begin{tabular}{|l|}
875.18 \\
\end{tabular} & \begin{tabular}{|l|l|}
943.19 \\
\end{tabular} & $|1011.20| 1$ & 1163.12 & |1267.64 & 117.93 & 127.10 & 136.26 & \begin{tabular}{|l|l|}
156.73 \\
\end{tabular} & 170.82 & 421.92 & 454.70 & $\mid 487.49$ & \begin{tabular}{|l|}
560.73 \\
\end{tabular} & \begin{tabular}{|l|l|}
611.12 \\
\end{tabular} \\
\hline 9 & 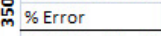 & & 0.75 & 0.84 & \begin{tabular}{|l|}
1.49 \\
\end{tabular} & 0.44 & 0.53 & 1.03 & 1.27 & 2.06 & 0.58 & 0.70 & 6.28 & 6.64 & 7.51 & 4.29 & 4.13 & 0.14 & 0.10 & 0.24 & 0.14 & 0.15 & 0.92 & 0.89 & 1.42 & 0.09 & 0.17 \\
\hline 10 & Total Rankine $\mathrm{Cy}_{y}$ & & \begin{tabular}{|l|l|}
130.44 \\
\end{tabular} & 141.79 & \begin{tabular}{|l|}
154.11 \\
\end{tabular} & 167.52 & $\mid 182.08$ & 122.62 & \begin{tabular}{|l|l|}
133.28 \\
\end{tabular} & \begin{tabular}{|l|l|l|l|}
144.87 \\
\end{tabular} & \begin{tabular}{|l|l|}
157.46 \\
\end{tabular} & \begin{tabular}{|l|}
171.16 \\
\end{tabular} & \begin{tabular}{|l|l|}
490.46 \\
\end{tabular} & \begin{tabular}{|l|l|}
533.11 \\
\end{tabular} & \begin{tabular}{|l|}
579.47 \\
\end{tabular} & \begin{tabular}{|l|l|}
629.86 \\
\end{tabular} & \begin{tabular}{|l||}
684.63 \\
\end{tabular} & 91.31 & \begin{tabular}{l|l}
99.25 \\
\end{tabular} & \begin{tabular}{l|l|}
107.88 \\
\end{tabular} & \begin{tabular}{|l|l|}
117.26 \\
\end{tabular} & \begin{tabular}{l|l|l|}
127.46 \\
\end{tabular} & 365.24 & \begin{tabular}{|l|l|}
397.00 \\
\end{tabular} & \begin{tabular}{|l|}
431.52 \\
\end{tabular} & \begin{tabular}{|l|l|}
469.04 \\
\end{tabular} & \begin{tabular}{|l|l|}
509.83 \\
\end{tabular} \\
\hline 11 & Model Predictio & & 129.39 & 142.29 & $\mid 155.19$ & 168.09 & 180.99 & 121.62 & \begin{tabular}{|l|}
133.75 \\
\end{tabular} & 145.88 & 158.00 & 170.13 & 486.49 & \begin{tabular}{|l|}
535.00 \\
\end{tabular} & 583.51 & \begin{tabular}{|l|l|}
632.01 \\
\end{tabular} & \begin{tabular}{|l|l|}
680.52 \\
\end{tabular} & 90.57 & 99.60 & 108.63 & \begin{tabular}{|l|}
117.66 \\
\end{tabular} & 126.69 & 362.28 & $\mid 398.40$ & 434.53 & \begin{tabular}{|l|l|}
470.65 \\
\end{tabular} & \begin{tabular}{|l|l|} 
& 506.77 \\
\end{tabular} \\
\hline 12 & \%Error & & 0.81 & 0.35 & \begin{tabular}{|l|}
0.70 \\
\end{tabular} & 0.34 & 0.60 & 0.81 & 0.35 & 0.70 & 0.34 & 0.60 & 0.81 & \begin{tabular}{|l|} 
\\
\end{tabular} & \begin{tabular}{|l|}
0.70 \\
\end{tabular} & \begin{tabular}{|l|} 
\\
\end{tabular} & $0.60 \mid$ & 0.81 & 0.35 & 0.70 & \begin{tabular}{|l|} 
\\
\end{tabular} & 0.60 & 0.81 & 0.35 & \begin{tabular}{|l|}
0.70 \\
\end{tabular} & 0.34 & 0.60 \\
\hline 13 & & & & & & & & & & & & & & & & & & & & & & & & & & & \\
\hline 14 & Total Less Power & Cycle & \begin{tabular}{|l|l|}
751.35 \\
\end{tabular} & 775.43 & \begin{tabular}{|l|}
801.18 \\
\end{tabular} & 919.62 & 969.93 & 640.60 & 664.78 & $690.80^{\prime}$ & 789.76 & 836.54 & 2041.26 & \begin{tabular}{|l|l|}
2109.92 & \\
\end{tabular} & \begin{tabular}{|l|l|}
2183.83 & 2 \\
\end{tabular} & 2464.90 & 2597.76 & 444.31 & 456.72 & 470.08 & 544.41 & 574.41 & 1414.27 & 1449.51 & $\mid 1487.431$ & 1698.54 & 1783.74 \\
\hline 15 & Model Predictio & & 780.97| & 803.62 & $|826.27|$ & 957.25 & 1010.00 & 660.44 & \begin{tabular}{|l|}
679.60 \\
\end{tabular} & 698.75 & 809.51 & 854.12 & 2079.81 & 2140.12 & $\left.2200.43\right|^{2}$ & 2549.25 & $2689.72 \mid$ & 444.16 & 457.04 & 469.92 & \begin{tabular}{|l|l|}
544.41 \\
\end{tabular} & 574.41 & 1398.70 & \begin{tabular}{|l|l}
1439.26 & \\
\end{tabular} & $\mid 1479.82$ & 1714.40 & 1808.88 \\
\hline 16 & \% Error & & 3.94 & 3.64 & \begin{tabular}{|l|}
3.13 \\
\end{tabular} & 4.09 & 4.13 & 3.10 & \begin{tabular}{|l|}
2.23 \\
\end{tabular} & 1.15 & 2.50 & 2.10 & \begin{tabular}{|l|}
1.89 \\
\end{tabular} & \begin{tabular}{|r|}
1.43 \\
\end{tabular} & \begin{tabular}{|l|}
0.76 \\
\end{tabular} & \begin{tabular}{|l|}
3.42 \\
\end{tabular} & \begin{tabular}{|l|}
3.54 \\
\end{tabular} & 0.04 & 0.07 & 0.03 & \begin{tabular}{|l|} 
\\
\end{tabular} & 0.00 & 1.10 & \begin{tabular}{|l|} 
\\
\end{tabular} & 0.51 & \begin{tabular}{|l|} 
\\
\end{tabular} & 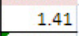 \\
\hline 17 tิ & Total Brayton Cy & & 384.11 & \begin{tabular}{l|l}
414.15 \\
\end{tabular} & \begin{tabular}{|l|}
446.73 \\
\end{tabular} & 505.16 & 550.16 & 337.97 & 364.98 & 394.29 & 442.52 & 481.77 & 1271.85 & 1375.48 & \begin{tabular}{|l|l|l|l|l|}
1487.98 & \\
\end{tabular} & \begin{tabular}{|c|c|}
1656.76 \\
\end{tabular} & 1802.81 & 163.52 & 175.70 & 188.90 & 217.09 & 236.60 & 586.13 & 631.14 & 679.95 & 772.29 & 841.06 \\
\hline 18 & $\boldsymbol{\Sigma}_{0}$ Model Predictior & & 384.65 & 414.54 & $\mid 444.43$ & 511.20 & 557.13 & 338.83 & \begin{tabular}{|l|}
365.16 \\
\end{tabular} & $391.49 \mid$ & 450.31 & 490.77 & 1212.21 & $1306.41 \mid$ & $|1400.61|_{1}$ & 1611.04 & $1755.80 \mid$ & 163.35 & 176.04 & 188.73 & \begin{tabular}{|l|l|}
217.09 \\
\end{tabular} & 236.60 & 584.39 & \begin{tabular}{|l|l|}
629.81 \\
\end{tabular} & $\mid 675.22$ & \begin{tabular}{|l|}
776.67 \\
\end{tabular} & \begin{tabular}{|l|l|}
846.46 \\
\end{tabular} \\
\hline 19 & ६్ \% \% Error & & 0.14 & 0.09 & \begin{tabular}{|l|}
0.51 \\
\end{tabular} & 1.20 & 1.27 & 0.25 & 0.05 & 0.71 & 1.76 & 1.87 & \begin{tabular}{|l|}
4.69 \\
\end{tabular} & \begin{tabular}{|l|}
5.02 \\
\end{tabular} & \begin{tabular}{|l|}
5.87 \\
\end{tabular} & \begin{tabular}{|l|}
2.76 \\
\end{tabular} & \begin{tabular}{|l|}
2.61 \\
\end{tabular} & 0.10 & 0.19 & 0.09 & \begin{tabular}{|l|}
0.00 \\
\end{tabular} & 0.00 & 0.30 & \begin{tabular}{|l|} 
\\
\end{tabular} & \begin{tabular}{|l|} 
\\
0.70 \\
\end{tabular} & 0.57 & 0.64 \\
\hline 20 & Total Rankine $\mathrm{CY}$ & & \begin{tabular}{|l|l|}
170.79 \\
\end{tabular} & 185.64 & \begin{tabular}{|l|}
201.78 \\
\end{tabular} & 219.33 & 238.40 & 160.54 & \begin{tabular}{|l|l|}
174.50 \\
\end{tabular} & 189.68 & 206.17 & 224.10 & \begin{tabular}{|l|l|}
642.17 \\
\end{tabular} & \begin{tabular}{|l|l|}
698.01 \\
\end{tabular} & \begin{tabular}{|l|}
758.70 \\
\end{tabular} & \begin{tabular}{|l|l|}
824.68 \\
\end{tabular} & \begin{tabular}{|l|l|}
896.39 \\
\end{tabular} & 119.55 & 129.95 & \begin{tabular}{l|l|l}
141.25 \\
\end{tabular} & \begin{tabular}{|l|l|}
153.53 \\
\end{tabular} & 166.88 & 478.21 & \begin{tabular}{|l|l|}
519.79 \\
\end{tabular} & \begin{tabular}{|l|}
564.99 \\
\end{tabular} & \begin{tabular}{|l|l|}
614.12 \\
\end{tabular} & 667.52 \\
\hline 21 & Model Predictio & & 169.41 & 186.30 & \begin{tabular}{|l|}
203.19 \\
\end{tabular} & 220.08 & 236.97 & 159.24 & \begin{tabular}{|l|}
175.12 \\
\end{tabular} & 191.00 & 206.88 & 222.75 & \begin{tabular}{|l|l|}
636.97 \\
\end{tabular} & \begin{tabular}{|l|l|}
7000.48 \\
\end{tabular} & $\mid 763.99$ & \begin{tabular}{|l|l|}
827.50 \\
\end{tabular} & \begin{tabular}{|l||}
891.01 \\
\end{tabular} & 118.58 & 130.41 & 142.23 & \begin{tabular}{|l|l|}
154.06 \\
\end{tabular} & 165.88 & 474.34 & \begin{tabular}{|l|}
521.63 \\
\end{tabular} & \begin{tabular}{|l|}
568.93 \\
\end{tabular} & \begin{tabular}{|l|l|}
616.22 \\
\end{tabular} & 663.52 \\
\hline 22 & \%Error & & 0.81 & 0.35 & \begin{tabular}{|l|} 
\\
0.70 \\
\end{tabular} & 0.34 & 0.60 & 0.81 & \begin{tabular}{|l|} 
\\
\end{tabular} & 0.70 & 0.34 & 0.60 & 0.81 & \begin{tabular}{|l|}
0.35 \\
\end{tabular} & \begin{tabular}{|l|} 
\\
0.70 \\
\end{tabular} & \begin{tabular}{|l|} 
\\
\end{tabular} & \begin{tabular}{|l|}
0.60 \\
\end{tabular} & 0.81 & 0.35 & 0.70 & \begin{tabular}{|l|} 
\\
\end{tabular} & 0.60 & 0.81 & \begin{tabular}{|l|}
0.35 \\
\end{tabular} & \begin{tabular}{|l|} 
\\
0.70 \\
\end{tabular} & \begin{tabular}{|l|} 
\\
\end{tabular} & \begin{tabular}{|l}
0.60 \\
\end{tabular} \\
\hline 23 & & & & & & & & & & & & & & & & & & & & & & & & & & & \\
\hline 24 & & & 750 & 800 & 850 & 900 & 950 & & & & & & & & & & & & & & & & & & & & \\
\hline 25 & $\bar{z} \%$ Efficiency & & 46.8 & 47.7 & 48.5 & 49.2 & 49.9 & & & & & & & & & & & & & & & & & & & & \\
\hline 26 & Power (MWe) - 3 & $50 \mathrm{MWt}$ & 163.8 & 166.95 & \begin{tabular}{|l|}
169.75 \\
\end{tabular} & 172.2 & 174.65 & & & & & & & & & & & & & & & & & & & & \\
\hline 27 & 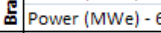 & $00 \mathrm{MWt}$ & 280.8 & 286.2 & 291 & 295.2 & 299.4 & & & & & & & & & & & & & & & & & & & & \\
\hline 28 & E Efficiency & & 44.5 & 45.3 & 46.1 & 46.8 & 47.5 & & & & & & & & & & & & & & & & & & & & \\
\hline 29 & 5 Power (MWe) - 3 & $50 \mathrm{MWt}$ & 155.75 & 158.55 & \begin{tabular}{|l|}
$\mid 161.35$ \\
\end{tabular} & 163.8 & 166.25 & & & & & & & & & & & & & & & & & & & & \\
\hline 30 & Power (MWe) - & $00 \mathrm{MWt}$ & 267 & 271.8 & \begin{tabular}{|l|}
276.6 \\
\end{tabular} & 280.8 & 285 & & & & & & & & & & & & & & & & & & & & \\
\hline 31 & & & & & & & & & & & & & & & & & & & & & & & & & & & \\
\hline 32 & & & & OT & & Reactc & & HTGR Size - & Base 600 & FOAK Ph & Phase & NGNP P & Phase & & & & & & & & & & & & & & \\
\hline 33 & HTGR Less Power & T Range & $T \leq 850^{8}$ & $850<T<900$ & $T>900$ & & & & & & & & & & & & & & & & & & & & & & \\
\hline $34 \mathrm{c}$ & HIG Less power & Slope & 0.2576 & 1.48667 & 0.6 & Exponent & 0.8275 & Exponent & 0.6734 & Multiplier & 1.487 & Multiplier & 1.7583 & & & & & & & & & & & & & & \\
\hline $35^{c}$ & & Int. & 250.95 & -793.598 & 4.4148 & & & & & & & & & & & & & & & & & & & & & & \\
\hline 36 & & T Range & $T \leq 850^{8}$ & $850<T<900$ & $T>900$ & & & & & & & & & & & & & & & & & & & & & & \\
\hline 37 B & Brayton Cycle & Slope & 0.2539 & 0.56373 & 0.3901 & Exponent & 0.9195 & Exponent & 0.6044 & Multiplier & 2.0743 & Multiplier & 2.3548 & & & & & & & & & & & & & & \\
\hline 38 & & Int. & -27.06 & -290.269 & -134.03 & & & & & & & & & & & & & & & & & & & & & & \\
\hline 39 & & T Range & & All T's & & & & & & & & & & & & & & & & & & & & & & & \\
\hline $40 \mathrm{R}$ & Rankine Cycle & Slope & & 0.23648 & & Exponent & & Exponent & 0.5 & Multiplier & 1.3429 & Multiplier & 1.4286 & & & & & & & & & & & & & & \\
\hline 41 & & Int. & & -58.7751 & & & & & & & & & & & & & & & & & & & & & & & \\
\hline
\end{tabular}

Figure 15. Correlations worksheet screenshot. 


\subsubsection{Named Cells/Ranges}

No named cells or ranges are included in the Correlations worksheet.

\subsubsection{Worksheet Formatting} inputs.

Cells highlighted pink include IF statements, other Excel functions, or equations dependent upon user

\subsubsection{Worksheet Equations/IF Statements}

All ROT correlations were developed using the costs for a single $600 \mathrm{MWt}$ unit for an NOAK project phase. The ROT correlation is developed using the SLOPE and INTERCEPT Excel functions. Both the HTGR and Brayton cycle correlations are linear step functions due to materials changed (INL 2011). The following equation is used to calculate the slope for ROTs less than $850^{\circ} \mathrm{C}$ for the HTGR with no power cycle:

$$
\text { D34=SLOPE(S14:U14,S3:U3) }
$$

where S14:U14 are the known y-values, and S3:U3 are the known $\mathrm{x}$-values. The following equation is used to calculate the intercept:

$$
\text { D35=INTERCEPT(S14:U14,S3:U3) }
$$

Similar equations are used for the remaining HTGR ROT ranges and for the Brayton and Rankine cycle ROT correlations. An exponential function is used in the correlation for the number of units. The exponent was determined by averaging the exponents for all ROTs for the single and four-pack NOAK costs. The following equation is used to set the exponent for the HTGR with no power cycle:

$$
\begin{aligned}
& \text { H34=AVERAGE(LN(X14/S14)/LN(4),LN(Y14/T14)/LN(4),LN(Z14/U14)/LN(4),LN(AA14/ } \\
& \text { V14)/LN(4),LN(AB14/W14)/LN(4)) }
\end{aligned}
$$

Again, similar equations are used for the Brayton and Rankine cycles. The correlation for reactor size is also in the form of an exponential function. The exponent was determined by averaging the exponents for all ROTs for the single $600 \mathrm{MWt}$ and $350 \mathrm{MWt}$ NOAK costs, $600 \mathrm{MWt}$ is the basis. The following equation is used to set the exponent for the HTGR with no power cycle:

$$
\begin{aligned}
& \text { J34=AVERAGE(LN(S14/S4)/LN(600/350),LN(T14/T4)/LN(600/350),LN(U14/U4)/LN(600/ } \\
& \text { 350),LN(V14/V4)/LN(600/350),LN(W14/W4)/LN(600/350)) }
\end{aligned}
$$

Similar equations are used for the Brayton and Rankine cycles; however the ratio of the power cycle sizes are used (rows 26, 27, 29, and 30) instead of the thermal rating ratio. It should be noted that the gross heat input to the power cycle could also be used in place of the power cycle size.

Finally, multipliers for the FOAK and NGNP plants were determined by averaging the multipliers for each ROT for the single $600 \mathrm{MWt}$ and $350 \mathrm{MWt}$ configurations, with the NOAK plant as the basis, i.e. a multiplier of one. The equation for the FOAK correlation for the HTGR with no power cycle is provided as an example:

$$
\begin{aligned}
& \text { L34=AVERAGE(AVERAGE((I14/S14),(J14/T14),(K14/U14),(L14/V14),(M14/W14)), } \\
& \text { AVERAGE((I4/S4),(J4/T4),(K4/U4),(L4/V4),(M4/W4))) }
\end{aligned}
$$

Both $600 \mathrm{MWt}$ and $350 \mathrm{MWt}$ plants were used to determine the reactor phase multipliers in order to minimize the percent error for a variety or reactor sizes. 
The correlations were then used to predict costs for the HTGR, Brayton cycle, and Rankine cycle. The calculation for a $350 \mathrm{MWt}$ NGNP HTGR with no power cycle and an ROT of $750^{\circ} \mathrm{C}$ (cell D5) is provided as the example:

$$
\begin{aligned}
& \mathrm{D} 5=\$ \mathrm{~N} \$ 34^{*}\left((350 / 600)^{\wedge} \$ \mathrm{JJ} \$ 34\right) *\left(\$ \mathrm{D} \$ 2^{\wedge} \$ \mathrm{H} \$ 34\right) * \mathrm{IF}\left(\mathrm{D} \$ 3<=850, \$ \mathrm{D} \$ 34^{*} \mathrm{D} \$ 3+\$ \mathrm{D} \$ 35, \mathrm{IF}(\mathrm{AND}(\right. \\
& \left.\left.\mathrm{D} \$ 3>850, \mathrm{D} \$ 3<=900), \$ \mathrm{E} \$ 34 * \mathrm{D} \$ 3+\$ \mathrm{E} \$ 35, \mathrm{IF}\left(\mathrm{D} \$ 3>900, \$ \mathrm{~F} \$ 34^{*} \mathrm{D} \$ 3+\$ \mathrm{~F} \$ 35,\right)\right)\right)
\end{aligned}
$$

For detailed descriptions of the correlations developed in the HTGR Cost Model see pages 22 through 29 of TEV-1196 (INL 2011).

\subsubsection{Worksheet Macros}

No Macros are included in the Correlations worksheet.

\section{REFERENCES}

AACE, 2005, Cost Estimate Classification System - As Applied in Engineering, Procurement, and Construction for the Process Industries, AACE International Recommended Practice No. 18R-97.

INL, 2011, “Assessment of High Temperature Gas-Cooled (HTGR) Capital and Operating Costs," Idaho National Laboratory, TEV-1196, Rev. 1, January 05, 2012.

Excel, 2007, Version 12.0, Redmond, Washington: Microsoft Corporation, 2007.

NRC, 2010, Report of Waste Burial Charges: Changes in Decommissioning Waste Disposal Costs at Low-Level Waste Burial Facilities, NUREG-1307, Rev. 14. 